\title{
The South America Monsoon Circulation and Its Relationship to Rainfall over West-Central Brazil
}

\author{
M. A. GAN \\ National Institute for Space Research (INPE) of Brazil, Sao Paulo, Brazil \\ V. E. Kousky \\ National Centers for Environmental Prediction, Camp Springs, Maryland \\ C. F. ROPELEWSKI \\ International Research Institute for Climate Prediction, Palisades, New York
}

(Manuscript received 22 November 2002, in final form 14 May 2003)

\section{ABSTRACT}

\begin{abstract}
The mean atmospheric circulation for the rainy season over west-central Brazil $\left(20^{\circ}-10^{\circ} \mathrm{S}, 60^{\circ}-50^{\circ} \mathrm{W}\right)$ is investigated for a $21-y r$ period (July 1979-June 2000). The NCEP-NCAR reanalysis, pentad outgoing longwave radiation (OLR), and daily gridded precipitation analyses from NCEP are used in this study. The analysis presented here provides an improved description of the mean annual cycle based on daily and pentad (5-day) rainfall and atmospheric circulation data. The pentad precipitation averaged for the study region shows a rapid increase during the spring months (September-November) and a rapid decrease in April. The rainiest period (more than $8 \mathrm{~mm}$ day $^{-1}$ ) is from December to February. There are distinct wet (7 months) and dry (5 months) seasons, with approximately $90 \%$ of the total annual rainfall occurring during October-April.

The rainy season begins following the period when temperature is at its seasonal maximum. The pre-rainyseason warmth acts to destabilize the atmosphere and to create a reversal in the low-latitude temperature gradient. This results in a reversal of the vertical shear of the zonal wind from increasing (decreasing) westerly (easterly) winds with height to decreasing (increasing) westerly (easterly) winds with height. The examination of the vertical structure of the average zonal wind over the area reveals that prior to the onset of the rainy season easterlies prevail in the lower troposphere (up to $600 \mathrm{hPa}$ ) and westerly winds prevail at upper levels with maximum speed in the layer 200-150 hPa. During the rainy season the vertical structure of zonal wind is opposite to that of winter (June-August).

Within each rainy season, west-central Brazil experiences anomalously wet and dry periods. Wet periods are associated with low-level northwesterly and westerly flow east of the Andes that converges on west-central Brazil. Dry periods are associated with enhanced northwesterly flow over Paraguay and northern Argentina, and easterly anomalies over west-central Brazil.
\end{abstract}

\section{Introduction}

The seasonal cycle of precipitation over tropical South America shows characteristics of a monsoon system, with distinct wet and dry seasons for many areas from the equator south to $25^{\circ} \mathrm{S}$. More than $50 \%$ of the total annual precipitation over most of tropical and subtropical South America occurs during the austral summer [December-February (DJF); Rao and Hada 1990; Figueroa and Nobre 1990] in the form of convective rain with a strong diurnal variation (Silva Dias et al. 1987; Aceituno and Montecinos 1993). Although this is a typical feature of monsoons, Ramage (1971) did

Corresponding author address: Dr. M. A. Gan, INPE, CP515, 12201-970 Sao Jose dos Campos, Sao Paulo, Brazil.

E-mail: alonso@cptec.inpe.br not consider South America as having a true monsoon because, as far as he was able to determine, the lowlevel winds do not reverse their direction, as occurs with the Southeast Asian monsoon. Ramage attributed the nonexistence of the South America monsoon system (SAMS) to (a) the narrowness of the continent in the extratropics, which limits the area where stationary polar highs or heat lows can form, and (b) the persistent oceanic upwelling along the west coast, which keeps the sea surface temperature lower than the surface air over the continent throughout the year.

Recently, Zhou and Lau (1998) concluded that a monsoon system does exist over South America, based on the seasonal evolution of several atmospheric circulation features. During the austral summer low-level northeasterly flow enters tropical South America from 
the Atlantic. The low-level flow turns southward near the Andes with northerly and northwesterly winds over western Brazil, eastern Bolivia, and Paraguay. At upper levels a well-defined anticyclonic circulation exists near the region of maximum precipitation. The outflow from this upper-level anticyclone streams northward into the Northern Hemisphere. Similar features are observed in the boreal summer in the region of the East Asian monsoon.

The development of the SAMS starts during the spring season [September-November (SON)], as deep convection develops first over the northwestern Amazon basin in mid-September and then progresses southeastward, arriving in southeast Brazil by mid-October (Kousky 1988; Horel et al. 1989; Marengo et al. 2001). The maximum rainfall intensity occurs during the summer (DJF) when deep convection develops over much of tropical South America. The moisture transport from the Atlantic Ocean and evapotranspiration from the Amazon forest contribute to the precipitation over central and southeast Brazil (Rao et al. 1996). The moisture transport has a maximum during austral summer months and a minimum during winter months.

Monsoon-related changes in the circulation also occur at the upper levels. During the winter the flow tends to be zonal while during the summer the flow is weaker and more meridional, especially near the east and west coasts of South America. During the austral spring a closed upper-level anticyclonic circulation develops rapidly over the northwestern Amazon, which is directly related to the intense sensible heating of the elevated land surfaces of the Andean Altiplano (Zhou and Lau 1998) and latent heat released in thunderstorms. The sensible heating is associated with intense solar radiation, which increases the surface temperature and the vertical mixing by dry convection. During this period, the maximum in deep convection is generally oriented zonally (Horel et al. 1989). Subsequently, precipitation develops over the high terrain in central and southeastern Brazil and the latent heat release from the deep cumulus convection becomes the dominant heating mechanism (Rao and Erdogan 1989).

During the austral summer, an upper-tropospheric anticyclone (known as the Bolivian high) is observed over Bolivia and a trough appears over the Atlantic Ocean close to the coast of northeast Brazil (e.g., Virji 1981; Kousky and Ropelewski 1997). Studies, using atmospheric models (Silva Dias et al. 1983; De Maria 1985; Figueroa et al. 1995), show that the Bolivian high is strongly related to latent heat release from deep convection over the Amazon basin, and that its development is consistent with the Rossby wave response to tropical heating (e.g., Matsuno 1966; Gill 1980).

The decay phase of the monsoon begins in late summer, as deep convection gradually shifts equatorward (Kousky 1988; Horel et al. 1989). During the austral fall season [March-May (MAM)], the low-level eastward flow of moisture from the western Amazon weak- ens, and more frequent incursions of drier and cooler air from the midlatitudes begin to affect the interior of subtropical South America (WMO 1998).

As in other parts of the world, monsoon precipitation over tropical South America has variability on time scales ranging from high-frequency fluctuations associated with day-to-day weather to interannual variations associated with the ENSO cycle. Several studies have linked subseasonal variability of deep convection over eastern South America to intraseasonal (30-60 day, Madden-Julian) oscillations (e.g., Weickmann 1983; Weickmann et al. 1985; Kousky 1985; Kousky and Cavalcanti 1988; Kousky and Kayano 1994). Interannual variability of deep convection (precipitation) over portions of tropical and subtropical South America has been related to the El Niño-Southern Oscillation cycle (e.g., Kousky et al. 1984; Ropelewski and Halpert 1987; Aceituno 1988; Kousky and Ropelewski 1989; Kousky and Kayano 1994).

In some parts of the Amazon basin, the dates for the onset and demise of the rainy season are affected by the Atlantic and Pacific SST patterns (Marengo et al. 2001). However, in the southeast Amazon region there is no apparent relationship between the SST patterns and the onset and demise dates. In that region, convection is more closely related to land surface temperatures (Fu et al. 1998).

One aim of this study is to document the main changes in the atmospheric circulation over the South American region during the seasonal transition periods from dry to wet and from wet to dry in west-central Brazil $\left(10^{\circ}-\right.$ $20^{\circ} \mathrm{S}, 60^{\circ}-50^{\circ} \mathrm{W}$, hereafter referred to as WCB). We also examine the behavior of the atmospheric circulation during anomalously wet and dry periods within the rainy season. This study provides a more detailed examination of rainfall in WCB as it relates to the evolution of circulation patterns associated with the South American monsoon system. WCB includes a portion of the summertime rainfall maximum where the mean annual cycle of circulation is highly related to the South America monsoon system. This region is also important because it contains the western portion of the Brazilian Planalto and the headwaters of major rivers, such as Araguaia and Paraguay, which flow into the Amazon and La Plata basins, respectively.

In section 2 we describe the datasets and the criteria used to identify the monsoon onset and demise dates. In section 3 we document aspects of the seasonal cycle, with emphasis on contrasts between the wet and dry seasons. The onset and demise circulation composites are described in section 4 , and the atmospheric features that accompany exceptionally wet and dry periods within the rainy season are presented in section 5. Section 6 contains our discussion and conclusions.

\section{Data and methodology}

The data used in this study are

1) Pentad (5-day averaged) outgoing longwave radia- 


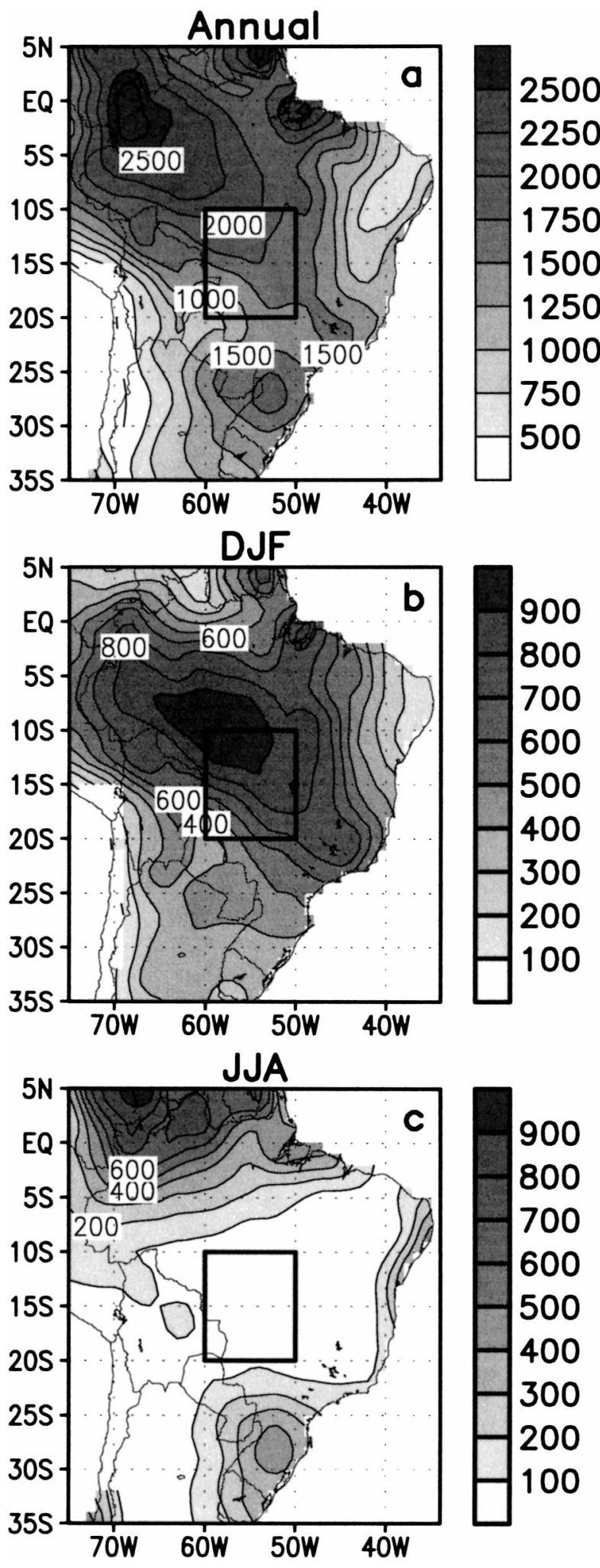

FIG. 1. Mean 1979-95 (a) annual, (b) summer (DJF), and (c) winter (JJA) precipitation for Brazil and adjacent areas. Contour interval is $250 \mathrm{~mm}$ in (a) and $100 \mathrm{~mm}$ in (b) and (c). The box denotes the study area of WCB.

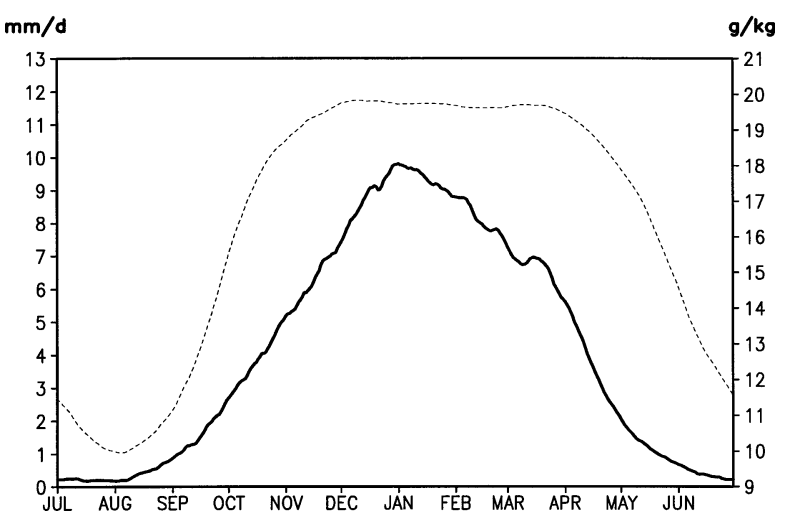

FIG. 2. Mean 1979-95 daily precipitation (mm, solid line) and 925$\mathrm{hPa}$ specific humidity ( $\mathrm{g} \mathrm{kg}^{-1}$, dashed line), averaged over the study area (see Fig. 1). Daily values have been smoothed using a 31-day running mean.

tion (OLR) for the period from July 1979 to June 2000.

2) Daily averaged fields of air temperature, wind, and specific humidity for July 1979-June 2000 from the National Centers for Environmental Prediction-National Center for Atmospheric Research (NCEPNCAR) reanalysis (Kalnay et al. 1996). (Note: the NCEP-NCAR reanalysis is somewhat limited by relative lack of observational data that it needs for input thus providing a limitation on this study.)

3) Gridded daily precipitation analyses for Brazil and gridded monthly precipitation analyses for South America, produced by the Climate Prediction Center. The data are analyzed on a $1^{\circ}$ latitude $\times 1^{\circ}$ longitude grid, using the Brazilian National Agency of Electric Energy (Agencia Nacional de Energia Eletrica) precipitation data for January 1979-December 1997. Monthly analyses also include data from World Meteorological Organization (WMO) stations that are reported through the Global Telecommunication System. The monthly analyses are used to describe the spatial patterns of precipitation (see the beginning of section 3). Elsewhere in this paper, the daily precipitation analyses for Brazil are used.

Several criteria for determining rainy season onset and demise dates have been applied to the monsoon regions of the world. Some of the criteria are based on rainfall (Nicholls et al. 1982), winds (e.g., Troup 1961; Ramage 1971; Murakami and Sumi 1982) or cloudiness (Davidson et al. 1983, 1984). For South America, Marengo et al. (2001) used a precipitation threshold to identify the monsoon onset date over five areas in the Amazon region, while Kousky (1988) used pentad OLR data to identify the rainy season onset date over tropical South America.

In this study we define the onset (demise) of the rainy season as the first occurrence of $850-\mathrm{hPa}$ westerly (easterly) winds along $60^{\circ} \mathrm{W}$ in the band $10^{\circ}-20^{\circ} \mathrm{S}$ together with rainfall rates greater (less) than $4 \mathrm{~mm} \mathrm{day}^{-1}$ for at 

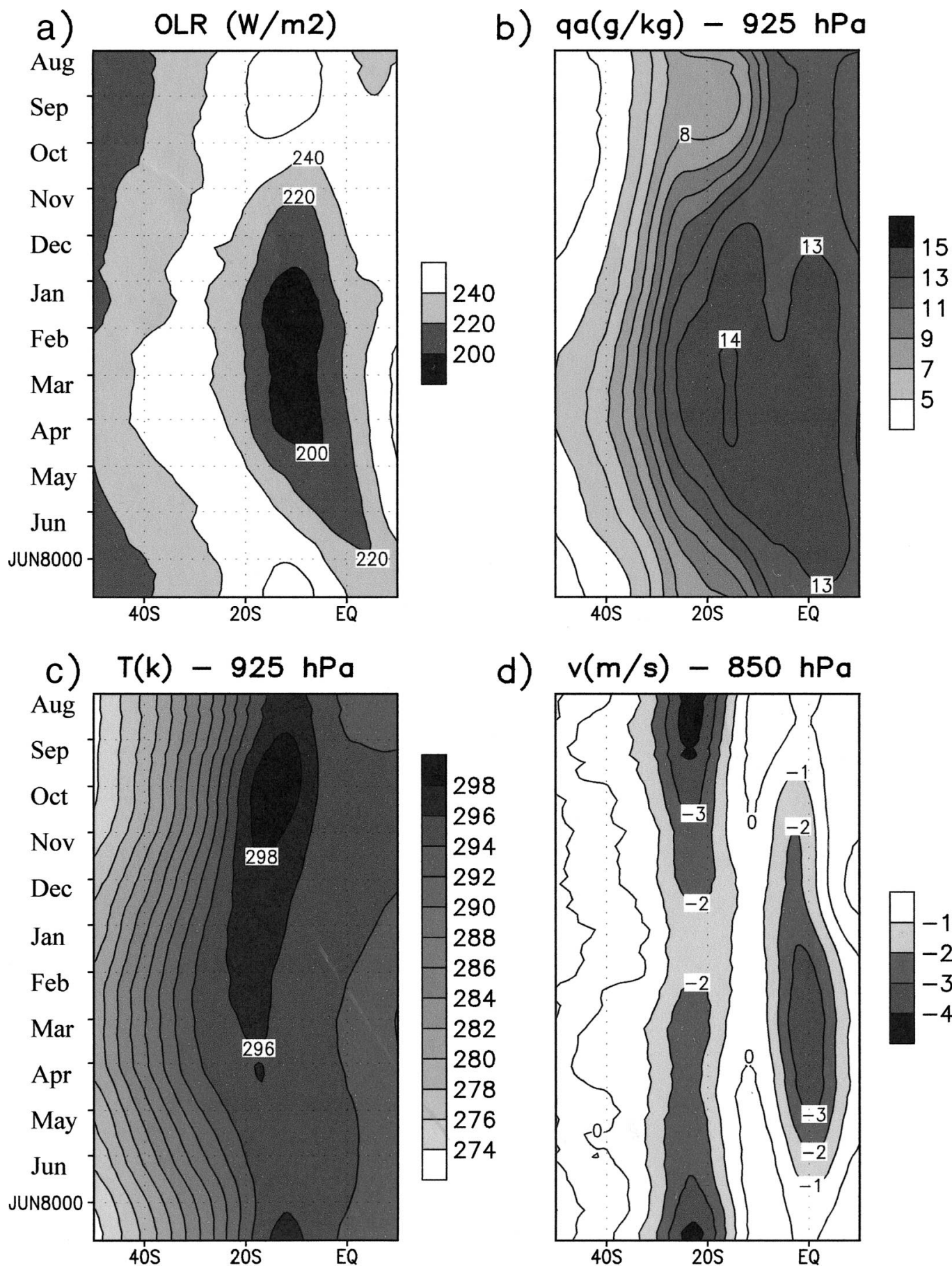

d)
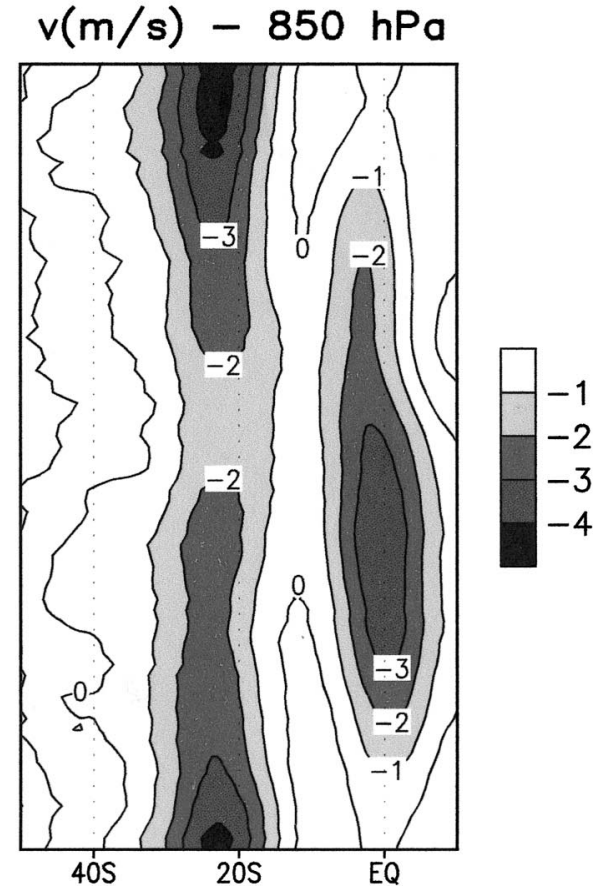

FIG. 3. Time-latitude section, averaged over $50^{\circ}-60^{\circ} \mathrm{W}$, for (a) outgoing longwave radiation $\left(\mathrm{W} \mathrm{m}^{-2}\right),(\mathrm{b}) 925-\mathrm{hPa}$ specific humidity $\left(\mathrm{g} \mathrm{kg}^{-1}\right)$, (c) $925-\mathrm{hPa}$ temperature $(\mathrm{K})$, and (d) $850-\mathrm{hPa}$ meridional wind $\left(\mathrm{m} \mathrm{s}^{-1}\right)$.

least $75 \%$ of the subsequent 8 pentads. The onset and demise dates form the basis for making composites of selected atmospheric circulation features to document the changes that occur during the onset and demise of the rainy season. Composite charts are also created for exceptionally wet and dry periods during the rainy season in central Brazil. As in Hendon and Liebmann
(1990), we assume that the onset (demise) is similar in each year and that the same mechanisms are involved.

\section{Climatic aspects}

The mean 1979-95 precipitation over Brazil shows three maxima in the annual totals (Fig. 1a): one over 


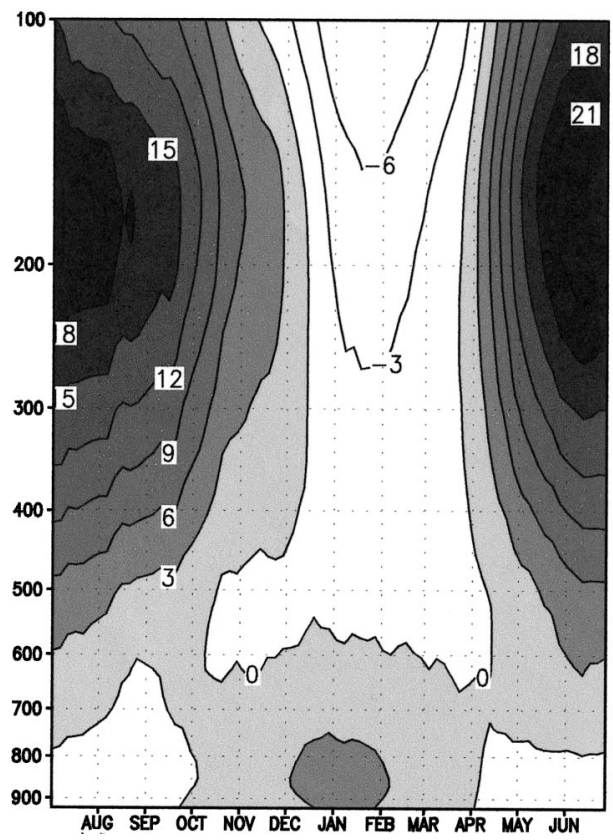

FIG. 4. Time-pressure section of the climatological zonal wind ( $\mathrm{m}$ $\mathrm{s}^{-1}$ ) at $15^{\circ} \mathrm{S}, 60^{\circ} \mathrm{W}$. Pentad values have been temporally smoothed using a 7-pentad running mean.

the northwestern Amazon near the border with Colombia and northern Peru, another over the northern coast at the mouth of the Amazon River, and a weaker maximum over the southern states. A minimum is observed over the northeast. There is a remarkable contrast between the summer and winter precipitation patterns, es- pecially in WCB, with some sections featuring more than $900 \mathrm{~mm}$ during summer (DJF, Fig. 1b) and less than $100 \mathrm{~mm}$ during winter (JJA, Fig. 1c). The regions of the other two rainfall maxima in annual precipitation show much less seasonality.

The rainy season over tropical Brazil starts at different times, beginning first over the north and west portion of the Amazon region in mid-September and over the southeast Amazon in October (Kousky 1988; Marengo et al. 2001). The 31-day smoothed daily mean (197997) time series of rainfall and $925-\mathrm{hPa}$ specific humidity over WCB (Fig. 2) show well-defined annual cycles with a very dry season (less than $1.0 \mathrm{~mm} \mathrm{day}^{-1}$ and $q$ $\approx 9 \mathrm{~g} \mathrm{~kg}^{-1}$ ) during JJA, a rapid increase of the precipitation and specific humidity during $\mathrm{SON}$, and a rapid decrease of precipitation (specific humidity) in AprilMay (May-June). Approximately $90 \%$ of the total annual rainfall in WCB occurs during the period from October to April, with the rainiest period (more than 8 $\mathrm{mm}$ day $^{-1}$ ) occurring during DJF. Specific humidity at 925-hPa remains essentially constant from November through March.

We also examined the mean seasonal evolution of deep convection over WCB using pentad OLR for the period July 1979-June 1997 (Fig. 3a). The climatological values of OLR decrease rapidly from mid-September to late October, indicating an increase in the amount and frequency of occurrence of cold clouds, an increase in precipitation, and the onset of the rainy season. The lowest values of OLR occur in December in the latitude band $5^{\circ}-15^{\circ} \mathrm{S}$, with values less than $240 \mathrm{~W} \mathrm{~m}^{-2}$ extending as far south as $25^{\circ} \mathrm{S}$. In March the low values
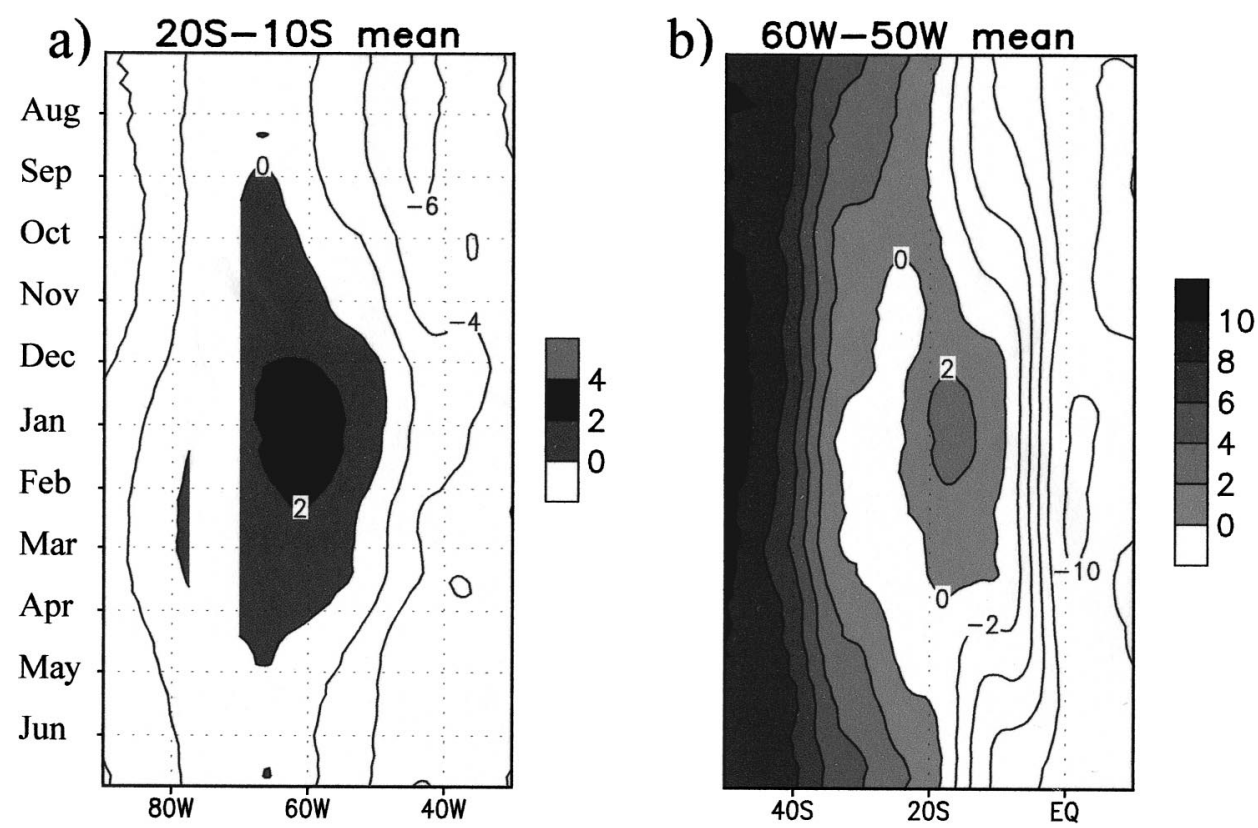

FIG. 5. Climatolgical $850-\mathrm{hPa}$ zonal wind $\left(\mathrm{m} \mathrm{s}^{-1}\right)$ : (a) time-longitude section averaged over $10^{\circ}-20^{\circ} \mathrm{S}$, and (b) time-latitude section averaged over $50^{\circ}-60^{\circ} \mathrm{W}$. Pentad values have been temporally smoothed using a 7-pentad running mean. (b) Areas where the $850-\mathrm{hPa}$ level is below the surface are blanked out. 

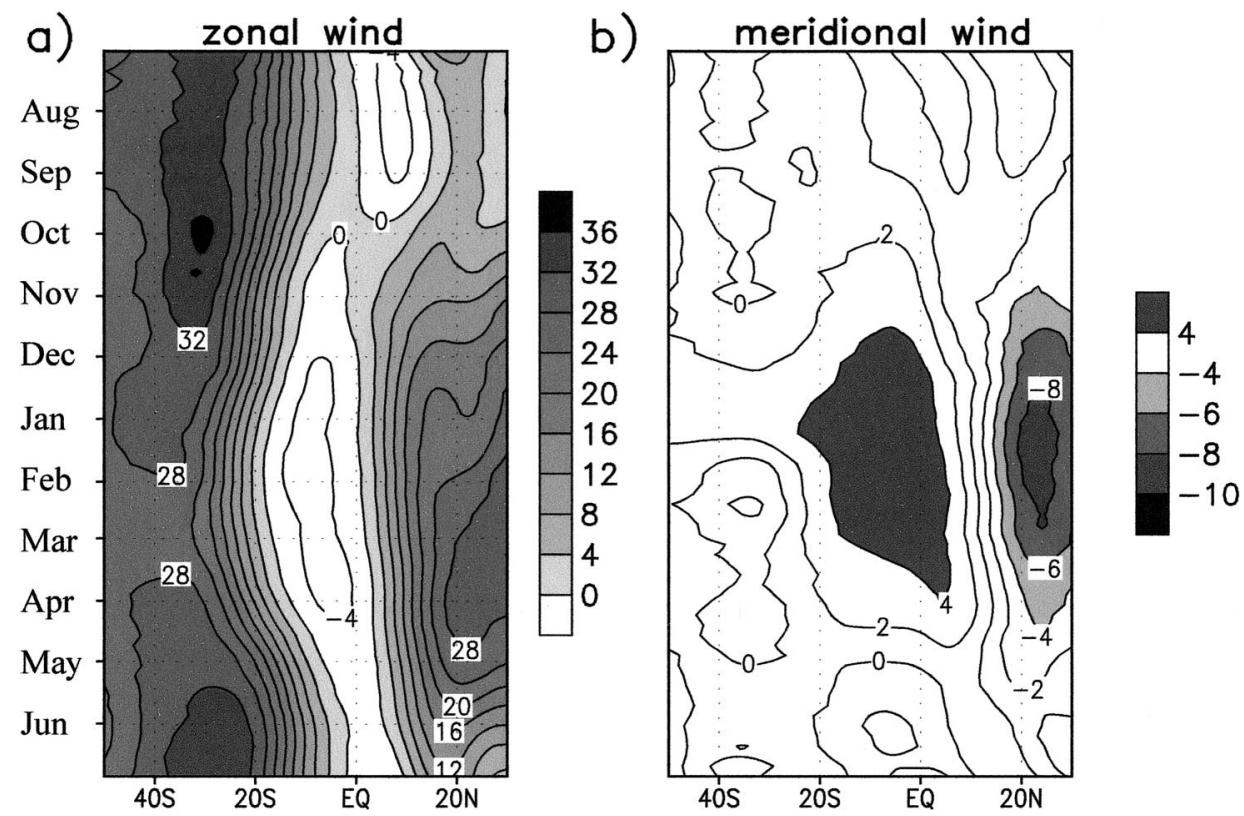

FIG. 6. Climatological 200-hPa (a) zonal and (b) meridional wind components $\left(\mathrm{m} \mathrm{s}^{-1}\right)$, averaged over $50^{\circ}-60^{\circ} \mathrm{W}$. Pentad values are smoothed using a 7 -pentad running mean.

of OLR begin to shift northward, but the withdrawal of deep convection during MAM occurs at a slower rate than the advance of deep convection during SON.

The evolution of the climatological specific humidity (Fig. 3b) is consistent with that shown for OLR (Fig. 3a), with large specific humidity increases at $925 \mathrm{hPa}$ occurring in SON as OLR decreases. South of $10^{\circ} \mathrm{S}$, specific humidity displays a well-defined annual cycle with a minimum during JAS and a maximum during JFM. To the north of this region, near the equator, the seasonal cycle is quite weak. It is also interesting to note that there is an approximate 1-month lag between OLR (deep convection and precipitation) and specific humidity during the demise phase of the rainy season. OLR and precipitation (see Fig. 2) decrease rapidly in

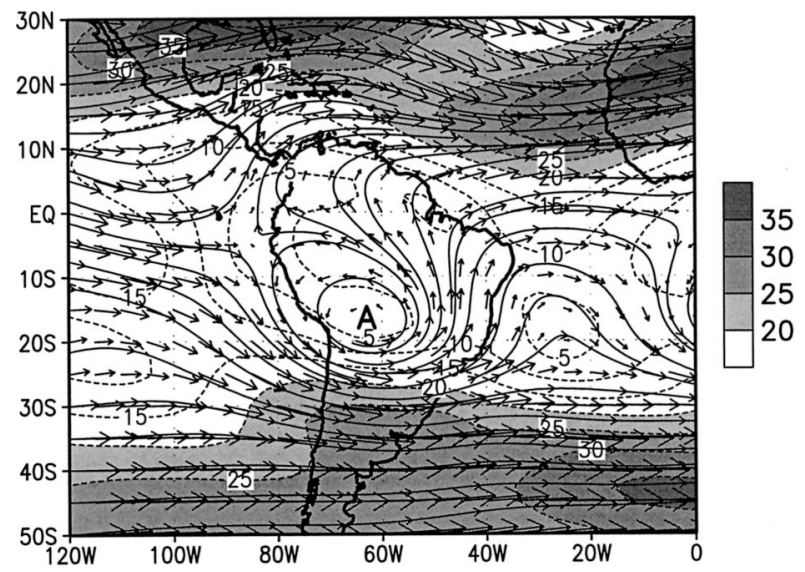

FIG. 7. Mean 1979-95 200-hPa streamlines and isotachs for DJF. The isotach contour interval is $5 \mathrm{~m} \mathrm{~s}^{-1}$. this region during April, whereas specific humidity decreases rapidly in the latitude band $5^{\circ}-15^{\circ} \mathrm{S}$ during May.

The temperature at $925 \mathrm{hPa}$ (Fig. 3c) also shows a distinct annual cycle, with the maximum at $15^{\circ} \mathrm{S}$ occurring during August-September, which is the end of the dry season and beginning of the rainy season. This maximum together with relatively cooler air to the north, results in an easterly thermal wind (easterly vertical wind shear) equatorward of the maximum, which is a feature typically found in other monsoon regions. These results agree with $\mathrm{Fu}$ et al. (1999), who found that the onset of the rainy season in the southern Amazon is sensitive to small changes in the atmospheric dynamic and thermodynamic structures.

The climatological time-latitude section of $850-\mathrm{hPa}$ meridional wind (Fig. 3d) shows a distinct annual cycle near and north of the equator, with maximum northerly winds occurring during DJFM and weak northerly winds during JJA. In the Southern Hemisphere subtropics the maximum northerly winds occur during the austral winter months.

An examination of the vertical structure of the average zonal wind (Fig. 4) at $15^{\circ} \mathrm{S}, 60^{\circ} \mathrm{W}$ reveals that prior to the onset of the rainy season easterly winds prevail in the lower troposphere (up to $800 \mathrm{hPa}$ ) and westerly winds occur at higher levels, with a maximum speed in the 200-150-hPa layer. A transition from easterly to westerly winds begins at the lowest levels in October and extends up to about $600 \mathrm{hPa}$ in November. During November-December upper-level westerly winds are replaced by easterly winds. Thus, the vertical structure of zonal wind during summer is opposite to that observed in winter. The summertime easterly ver- 
a)

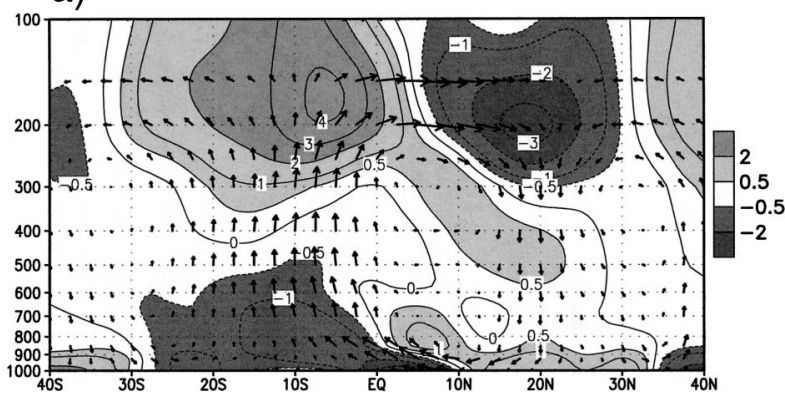

b)

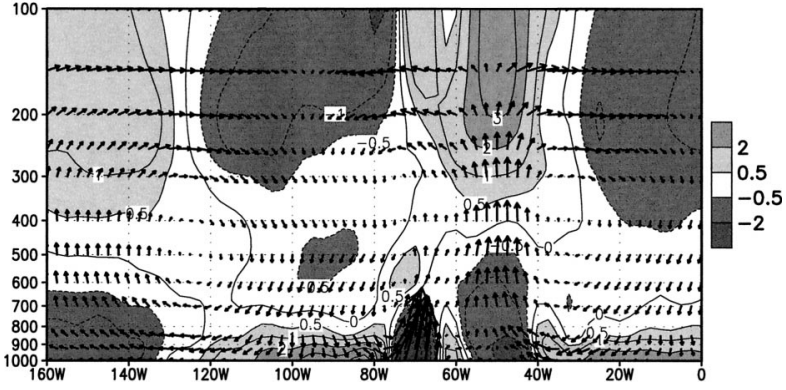

FIG. 8. Mean 1979-95 DJF (a) pressure-latitude section of the divergent circulation, averaged over $50^{\circ}-60^{\circ} \mathrm{W}$, and (b) pressure-longitude section of the divergent circulation, averaged over $10^{\circ}-20^{\circ} \mathrm{S}$. The divergent circulation is represented by vectors of combined pressure vertical velocity and divergent meridional wind in (a) and zona wind in (b). Solid (dashed) contours indicate divergence (convergence). Contour interval is $1 \times 10^{-6} \mathrm{~s}^{-1}$, with intermediate contours at $\pm 0.5 \times 10^{-6} \mathrm{~s}^{-1}$

tical shear is dynamically consistent with the low-level temperature gradient found equatorward of $20^{\circ} \mathrm{S}$ (Fig. $3 \mathrm{c})$. Another important monsoon feature in this figure is the appearance of the easterly wind maximum at 100 $\mathrm{hPa}$ during January with a speed of more than $9 \mathrm{~m} \mathrm{~s}^{-1}$. This bears some resemblance to the easterly jet observed

TABLE 1. Onset and demise dates (center of pentad) and length of rainy season (in pentads).

\begin{tabular}{crrc}
\hline \hline Years & Onset & Demise & Length \\
\hline $1979-80$ & $4 \mathrm{Nov}$ & $18 \mathrm{Apr}$ & 34 \\
$1980-81$ & $30 \mathrm{Oct}$ & $8 \mathrm{Apr}$ & 33 \\
$1981-82$ & $5 \mathrm{Oct}$ & $23 \mathrm{Apr}$ & 41 \\
$1982-83$ & $15 \mathrm{Sep}$ & $18 \mathrm{Apr}$ & 44 \\
$1983-84$ & $10 \mathrm{Oct}$ & $13 \mathrm{Apr}$ & 38 \\
$1984-85$ & $15 \mathrm{Oct}$ & $3 \mathrm{May}$ & 41 \\
$1985-86$ & $5 \mathrm{Oct}$ & $3 \mathrm{Apr}$ & 37 \\
$1986-87$ & $14 \mathrm{Nov}$ & $8 \mathrm{Apr}$ & 30 \\
$1987-88$ & $25 \mathrm{Oct}$ & $28 \mathrm{Apr}$ & 38 \\
$1988-89$ & $25 \mathrm{Oct}$ & $23 \mathrm{Apr}$ & 37 \\
$1989-90$ & $10 \mathrm{Oct}$ & $23 \mathrm{Apr}$ & 40 \\
$1990-91$ & $30 \mathrm{Sep}$ & $8 \mathrm{Apr}$ & 39 \\
$1991-92$ & $4 \mathrm{Nov}$ & $28 \mathrm{Apr}$ & 38 \\
$1992-93$ & $25 \mathrm{Sep}$ & $13 \mathrm{Apr}$ & 41 \\
$1993-94$ & $15 \mathrm{Oct}$ & $23 \mathrm{Apr}$ & 39 \\
$1994-95$ & $20 \mathrm{Oct}$ & $23 \mathrm{Apr}$ & 38 \\
$1995-96$ & $10 \mathrm{Oct}$ & $23 \mathrm{Apr}$ & 40 \\
$1996-97$ & $10 \mathrm{Oct}$ & $28 \mathrm{Apr}$ & 41 \\
\hline
\end{tabular}

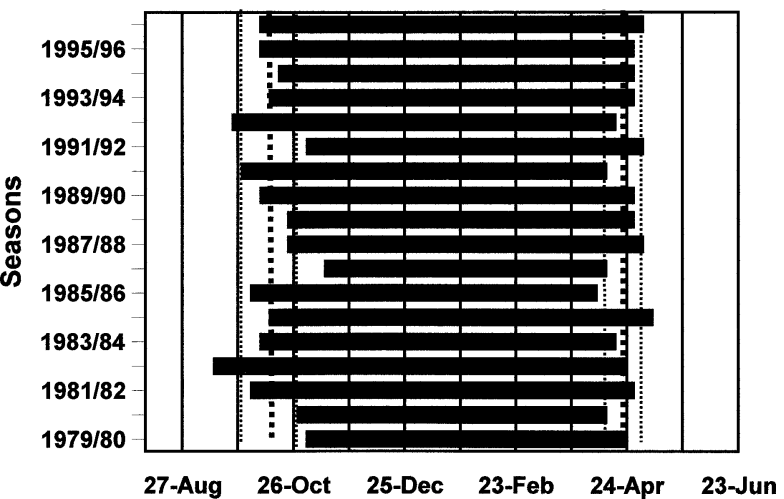

FIG. 9. Interannual variability of the rainy season in WCB. Vertical dotted lines indicate the 18-yr mean onset and demise dates (large dots) and \pm 1 std dev (small dots).

near $150 \mathrm{hPa}$ just to the west of the southern tip of India over the Arabian Sea during boreal summer, associated with the Asian monsoon (Koteswaran 1958; Krishnamurti and Bhalme 1976).

The time-longitude section for the $850-\mathrm{hPa}$ zonal winds, averaged over $20^{\circ}-10^{\circ} \mathrm{S}$ (Fig. 5a), shows a reversal in direction from easterly during the dry season (May-September) to westerly during the wet season (October-April) over the study region $\left(50^{\circ}-60^{\circ} \mathrm{W}\right)$. Considering the topography of the region, this shift in winds represents a change from downslope to upslope flow along the western flank of the Brazilian Planalto. The $850-\mathrm{hPa}$ westerly winds extend eastward to $48^{\circ} \mathrm{W}$ during the period from late November until mid-January, with maximum strength occurring near $60^{\circ} \mathrm{W}$ in December and January during the peak of the rainy season. The westerly winds over central and western tropical South America and the easterly winds to the east of that region are associated with mass convergence and ascending vertical motion over the region of study. The time-latitude section for $850-\mathrm{hPa}$ zonal wind (Fig. $5 \mathrm{~b}$ ), averaged over $60^{\circ}-50^{\circ} \mathrm{W}$, shows easterly winds equatorward of $20^{\circ} \mathrm{S}$ and westerly winds over the subtropics and lower midlatitudes during winter. In September the westerly winds in the subtropics $\left(25^{\circ}-30^{\circ} \mathrm{S}\right)$ weaken and weak easterly winds develop, as a summertime surface low-pressure system (Chaco low) forms over Paraguay and northern Argentina (Virji 1981). To the north of the Chaco low westerly winds are found as far north as $10^{\circ} \mathrm{S}$. The maximum of the westerly winds occurs during December and January coincident with the maximum in precipitation over WCB.

TABle 2. Minimum, mean, and maximum onset and demise dates (center of pentad), and the standard deviation (in pentads).

\begin{tabular}{lcccc}
\hline \hline & Min & Mean & Max & Std dev \\
\hline Onset date & 15 Sep & 15 Oct & 14 Nov & 3 \\
Demise date & $3 \mathrm{Apr}$ & $18 \mathrm{Apr}$ & $3 \mathrm{May}$ & 2 \\
Length (pentads) & 30 & 38 & 44 & 3 \\
\hline
\end{tabular}



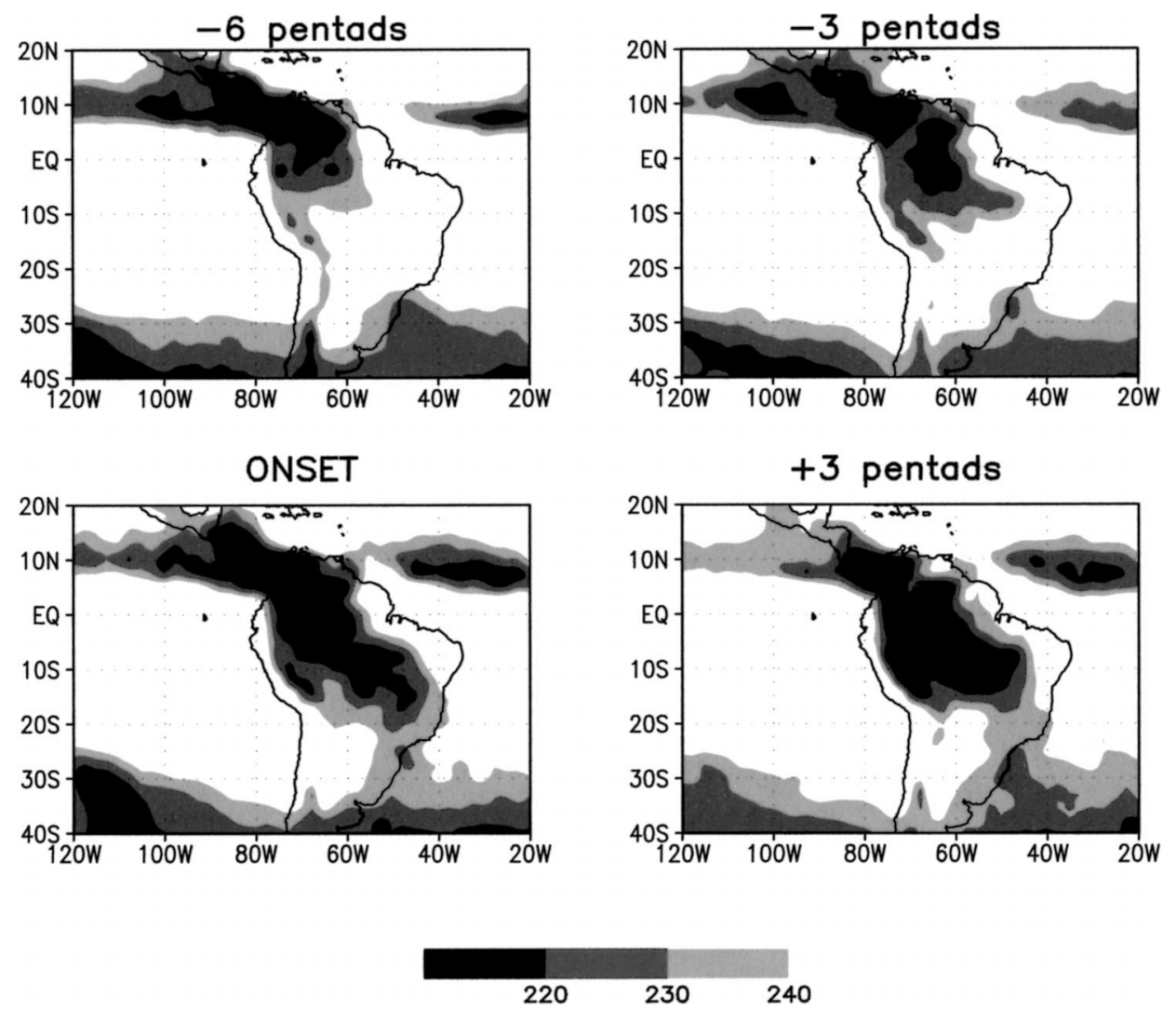

FIG. 10. OLR $\left(\mathrm{W} \mathrm{m}^{-2}\right)$ composites for the period prior to and immediately following the rainy season onset.

The 200-hPa zonal wind time-latitude section for the longitude band $50^{\circ}-60^{\circ} \mathrm{W}$ (Fig. 6a) shows weak easterly winds near the equator and westerly winds to the south and to the north of this region, with maximum westerly winds in the winter hemisphere. Both the easterly and the westerly winds display an annual cycle in the latitudinal position of the maxima, being more equatorward in the winter hemisphere and more poleward in the summer hemisphere. Over the northern portion of the study area $\left(10^{\circ}-15^{\circ} \mathrm{S}\right)$ the $200-\mathrm{hPa}$ zonal wind reverses its direction from westerly during winter to easterly during summer, which is out of phase with the low-level zonal wind changes. This reversal between low levels and high levels is observed in other convectively active regions in the Tropics (e.g., see Holland 1986 for a discussion concerning the Australian monsoon). Although Zhou and Lau (1998) showed that the low-level wind reverses when the mean annual cycle is removed, our results of the seasonal cycle clearly show that only the zonal wind reverses direction. In this respect, the South American monsoon is different from the Asian monsoon.

The time-latitude section for the 200-hPa meridional wind (Fig. 6b) shows mass confluence around $5^{\circ}-20^{\circ} \mathrm{N}$ from October to late April, associated with the confluence of west-northwesterly flow over the Caribbean and southerly flow emanating from the convection over trop- ical Brazil (Fig. 7). This confluence marks the entrance region of a subtropical jet stream that extends from the central North Atlantic eastward over northern Africa. The 850-hPa northerly winds (Fig. 3d) and the 200-hPa southerly winds (Fig. 6b) over northern South America reflect the presence of a regional Hadley circulation cell (Fig. 8a). The maximum upward vertical motion in DJF is located near $10^{\circ} \mathrm{S}$, associated with strong upper-level divergence and low-level convergence. Upper-level convergence over $5^{\circ}-30^{\circ} \mathrm{N}$ is associated with descending motion on the left flank of the North Atlantic subtropical jet entrance region (Fig. 7). The Hadley circulation is relatively weak and displaced to the north during the austral winter (JJA; figure not shown), with maximum rising motion over the latitude band $15^{\circ} \mathrm{S}-$ $12^{\circ} \mathrm{N}$ and sinking motion over the latitudes $15^{\circ}-40^{\circ} \mathrm{S}$ and $12^{\circ}-35^{\circ} \mathrm{N}$.

The east-west vertical section for the divergent circulation (vertical motion and zonal component of the divergent wind, derived from the velocity potential) during DJF, averaged over $10^{\circ}-20^{\circ} \mathrm{S}$ (Fig. 8b), shows a direct east-west thermal circulation with ascending air over the relatively warmer continent $\left(40^{\circ}-70^{\circ} \mathrm{W}\right)$ and descending air over the cooler Pacific and Atlantic Oceans. The strongest rising motion is slightly east of 

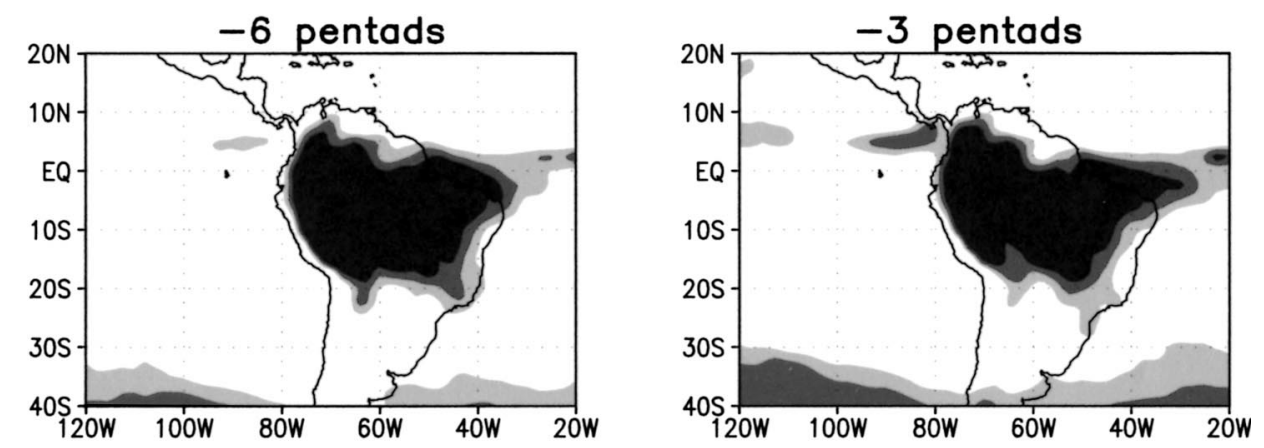

\section{DEMISE}
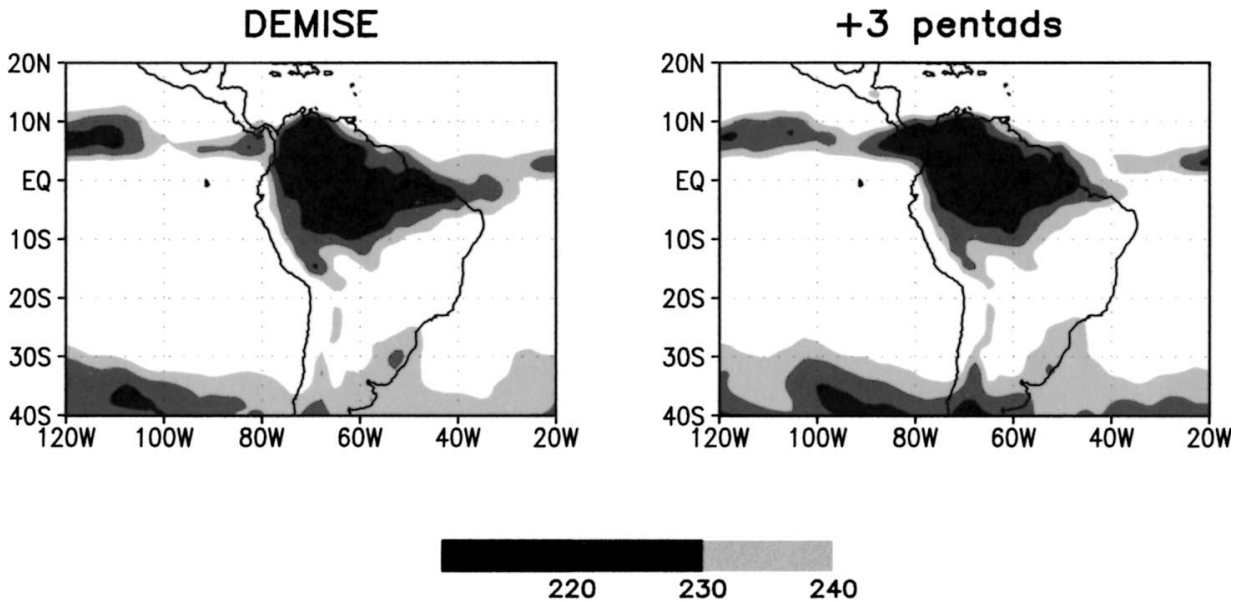

FIG. 11. As in Fig. 10 but for the rainy season demise.

the 200-hPa Bolivian high and the sinking motion occurs in the vicinity of the oceanic troughs (see Fig. 7).

\section{Rainy season onset and demise}

In this section we describe the time evolution of selected atmospheric fields relative to the onset and demise dates of the monsoon rains in WCB for each rainy season from 1979-80 to 1996-97, using the criteria defined in section 2. Table 1 and Fig. 9 show the pentads for the onset and the demise dates, and the length of each rainy season. The minimum, maximum, and mean pentads for the onset and demise, and their respective dates, are shown in Table 2. The average onset (demise) date of the rainy season for the entire record is 13-17 October (16-20 April). The standard deviation for the onset is 3 pentads and for the demise is 2 pentads, indicating more variability in the onset dates than in the demise dates (Fig. 9, Table 1). The longest rainy season occurred in 1982-83 (44 pentads), and the shortest in 1986-87 (30 pentads). The earliest and latest onset dates occurred in 1982 (13-17 September) and 1986 (12-16 November), respectively. Both of those years featured developing El Niño episodes. The earliest and latest demise dates occurred in 1986 (1-5 April) and 1985 (1-5 May), respectively. There is no obvious link between the ENSO cycle and the onset and demise dates for WCB, which is consistent with the results obtained for the southeast Amazon (Marengo et al. 2001).

After identifying the onset and demise dates, composites of atmospheric circulation fields over South America were constructed for both onset and demise transitions. The OLR composite maps for the onset (Fig. 10) show the progression of the monsoon rains from 6 pentads (30 days) before the onset date to three pentads (15 days) after onset. Six pentads before the monsoon onset in our study area rainfall is greatest over the northwestern Amazon region, Central America, and over the southeast North Pacific along the intertropical convergence zone (ITCZ). In subsequent pentads the deep convection shifts southeastward and intensifies progressively, as noted previously by Kousky (1988) and Marengo et al. (2001). On the onset date the OLR composite shows a northwest-southeast oriented band of low OLR values extending across South America. This pattern is partly due to the interaction between tropical convection and slow-moving midlatitude frontal systems that sometimes become stationary for several days over southeast Brazil, giving rise to the South Atlantic convergence zone (SACZ; Casarin and Kousky 1986; Kodama 1992). After the onset, convection remains active over a large part of tropical South America, except over the north and east coasts of Brazil and over the west coast of South America (west of Andes). Near the 

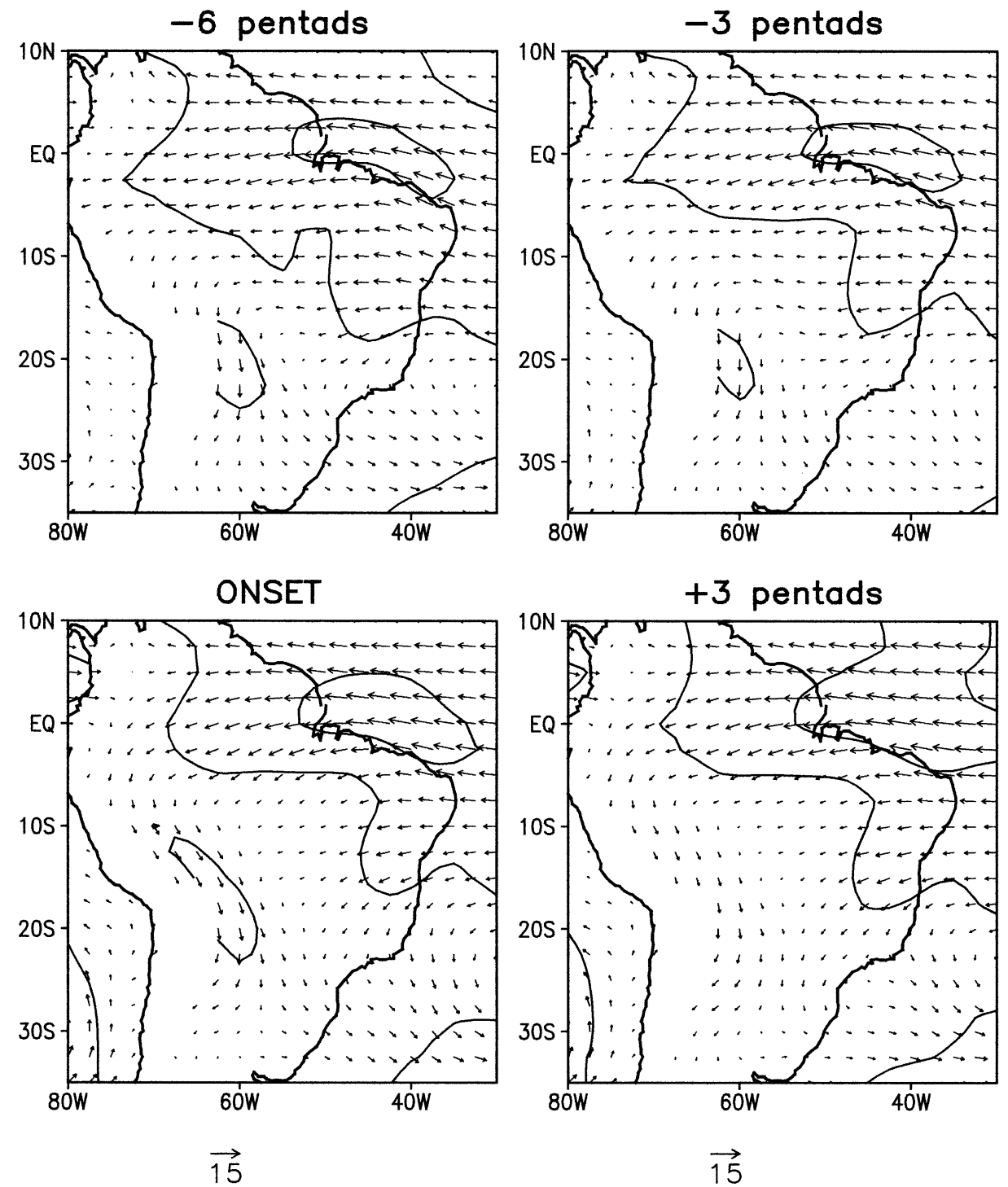

$\overrightarrow{15}$

FIG. 12. As in Fig. 10 except for $850-\mathrm{hPa}$ wind $\left(\mathrm{m} \mathrm{s}^{-1}\right)$.

end of the rainy season (Fig. 11), deep convection over tropical South America shifts northward, and develops a connection with the Atlantic ITCZ. On the demise date (Fig. 11d) the main area of convection is shifted north relative to its position on the onset date (Fig. 10d).

The composites of the low-level $(850 \mathrm{hPa})$ winds for the period prior to the onset of the rainy season (Fig. 12) show easterly flow perpendicular to the Andes between $10^{\circ} \mathrm{S}$ and $5^{\circ} \mathrm{N}$. On the onset date, the low-level flow near the Andes, between $5^{\circ}$ and $15^{\circ} \mathrm{S}$, develops a southward component and northwesterly flow, a feature noted in previous studies (e.g., Nogues-Peagle and Mo 1997; Berbery and Collini 2000). This northwesterly flow, together with pre-existing northwesterly flow between $15^{\circ}$ and $25^{\circ} \mathrm{S}$, acts to transport moisture from the western Amazon southward toward the Bolivian Altiplano, Paraguay, northern Argentina, and central and southern regions of Brazil. Over WCB the easterly winds weaken substantially at the onset of the rainy season and the low-level $(850 \mathrm{hPa})$ flow remains weak thereafter. During the demise phase (figures not shown) the opposite occurs, that is, the low-level easterly winds strengthen and remain relatively strong after the end of the rainy season.

During the onset phase the specific humidity increases quite rapidly from late August until mid-October (Fig. 13), which is similar to the seasonal changes noted previously for the long-term mean specific humidity (Fig. $2)$. In contrast, the rate of decrease of specific humidity during the demise phase is slower, probably due to feedbacks from accumulated soil moisture during the rainy season and evapotranspiration from vegetation.

The 200-hPa wind circulation during the onset period (Fig. 14) shows that prior to onset (6 pentads before), 

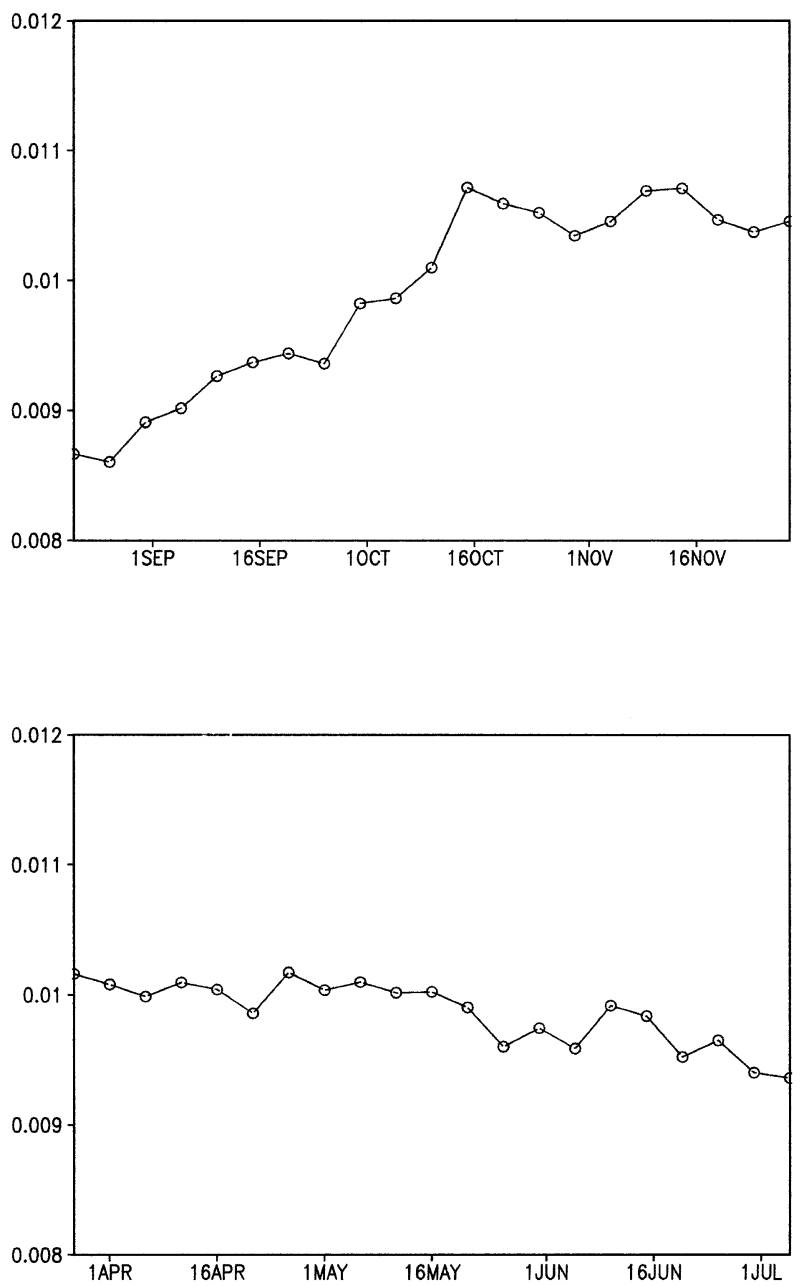

FIG. 13. Specific humidity at $850-\mathrm{hPa}\left(\mathrm{g} \mathrm{kg}^{-1}\right)$, averaged over $10^{\circ}-$ $15^{\circ} \mathrm{S}, 50^{\circ}-60^{\circ} \mathrm{W}$, for the period prior to and immediately following the rainy season (a) onset and (b) demise.

the flow is westerly over most of tropical South America, with the strongest winds over subtropical latitudes. Over the northwestern portion of the continent northeasterly winds are evident near the equator and anticyclonic circulation is found over the west-central Amazon near $5^{\circ} \mathrm{S}, 65^{\circ} \mathrm{W}$. The center of this circulation intensifies and propagates southward to $7.5^{\circ} \mathrm{S}, 65^{\circ} \mathrm{W}$ by the onset date and to its summertime climatological position $\left(15^{\circ} \mathrm{S}, 60^{\circ} \mathrm{W}\right.$ over Bolivia) three pentads later. Near the end of the rainy season the anticyclone weakens and shifts northeastward (figure not shown). In the composite for the demise (demise pentad 0), the anticyclone is $5^{\circ}$ latitude farther south than it was at the onset (onset pentad 0, Fig. 14). After the demise date, the anticyclone rapidly weakens and by pentad +4 it no longer has a closed circulation.

The evolution of the mean regional Hadley circulation, as it relates to the SAMS, is reflected in the onset and demise composites of vertical motion (Figs. 15 and 16). The onset is characterized by a transition from downward motion (omega $>0$ ) over the southern half of the study area preceding the onset $(-6$ and -3 pentads) to upward vertical motion (omega $<0$ ) throughout the study area at and following the onset. The reverse occurs during the demise phase of the rainy season in $\mathrm{WCB}$, as upward motion prior to the demise of the rainy season switches to downward motion in the southern half of the study area after the demise $(+3$ pentads in Fig. 16). The period prior to the onset of the rainy season in WCB features much weaker upward motion between $0^{\circ}$ and $15^{\circ} \mathrm{S}$ than does the period just after the demise of the rainy season (cf. Figs. 15 and 16).

The longitude-pressure cross sections for vertical velocity for $10^{\circ}-20^{\circ} \mathrm{S}$ during the onset phase (Fig. 17) show ascending motion over the continent, concentrated in the lower levels (up to $600 \mathrm{hPa}$ ), weak vertical motion in the middle and upper troposphere over the continent, and descending motion throughout the troposphere over both the Atlantic and Pacific oceans three to six pentads prior to onset. In the onset composite strong ascending motion is evident over central and west-central Brazil $\left(45^{\circ}-60^{\circ} \mathrm{W}\right)$ extending vertically throughout the troposphere, while descending motion dominates the troposphere over the Atlantic and Pacific Oceans. For the demise phase, the evolution of the atmospheric circulation (Fig. 18) is roughly opposite to that observed during the onset period.

\section{Extreme wet/dry periods}

Summertime (November-March) intraseasonal rainfall variability over tropical South America has been related to a number of atmospheric phenomena, such as the Madden-Julian oscillation (e.g., Weickmann 1983; Weickmann et al. 1985; Kousky 1985; Kousky and Cavalcanti 1988; Kousky and Kayano 1994; Madden and Julian 1972), subtropical upper-tropospheric cyclonic vortices (e.g., Kousky and Gan 1981), and incursions of midlatitude frontal systems (e.g., Kousky 1979; Liebmann et al. 1999). The higher-frequency phenomena (e.g., upper-tropospheric cyclonic vortices and frontal incursions), having periods between 2 and 30 days, account for most of the variability in rainfall observed in WCB during the rainy season (Liebmann et al. 1999). The focus of this section is on documenting the mean and anomalous atmospheric circulation features that accompany extreme wet and dry days during the peak of the rainy season in $\mathrm{WCB}$.

Composites were constructed in order to obtain the characteristic atmospheric features of extreme wet and dry periods in WCB during the peak of the rainy season (DJF). Since the results for December are similar to those for January, only the results for January are shown.

The January precipitation time series for 1979 through 1996 (Fig. 19) show considerable intramonthly variability, with daily values ranging from 1 to $21 \mathrm{~mm}$. In some years prolonged wet and dry periods occur 

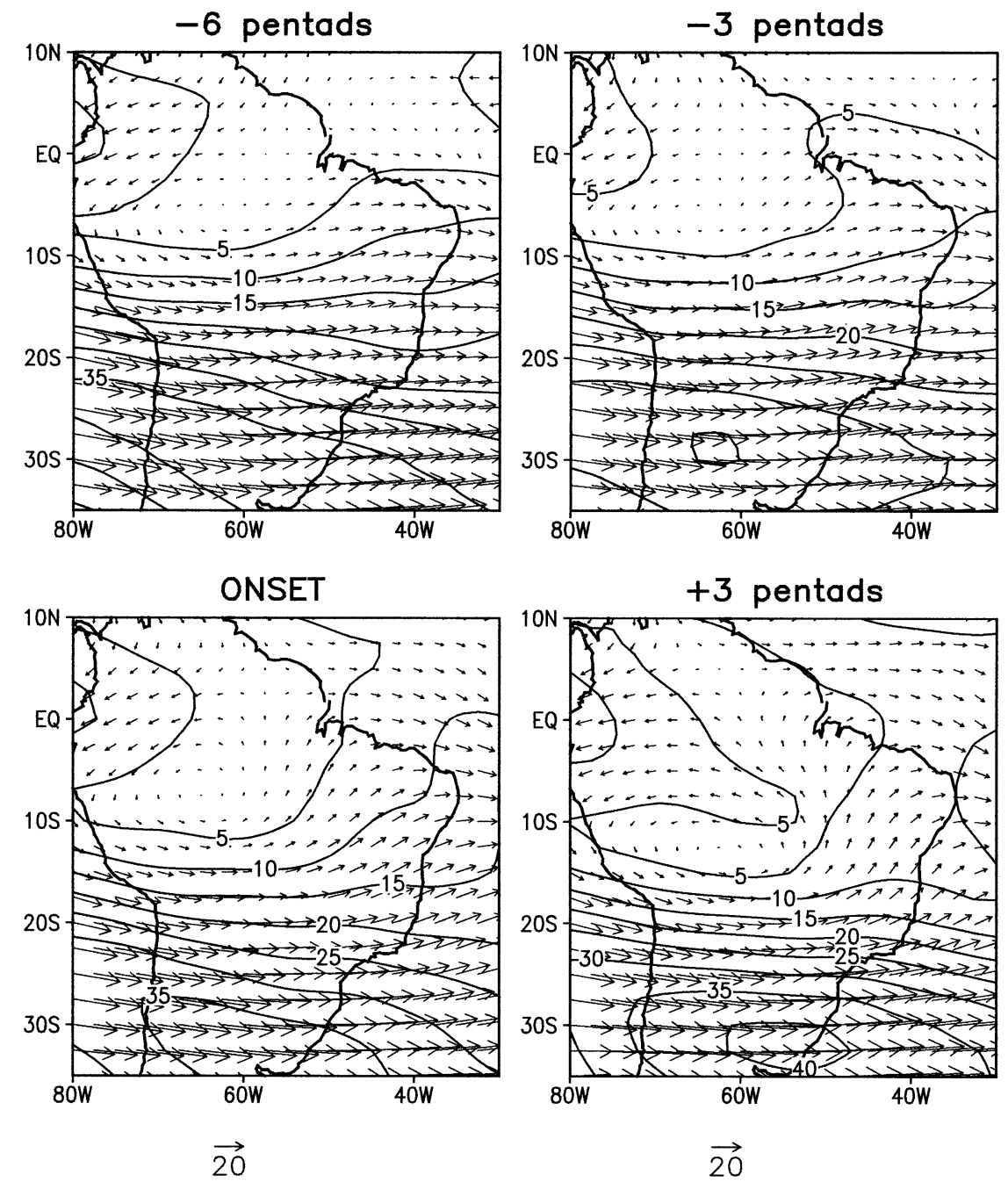

FIG. 14. Wind composites at $200-\mathrm{hPa}\left(\mathrm{m} \mathrm{s}^{-1}\right)$ for the period prior to and immediately following the rainy season onset. The isotach contour interval is $5 \mathrm{~m} \mathrm{~s}^{-1}$.

during the month (e.g., 1987, 1995, and 1996), while in other years rainfall totals were high or low throughout the month.

The January daily rainfall totals for WCB were first ranked in order from the highest value to the lowest value. The dates of the 30 highest and 30 lowest values, which represent approximately the upper and lower 5\% of the total distribution, were used in constructing the wet and dry composites for selected atmospheric variables. We also computed composites for the extreme wet and dry events, where we allowed only one day per event to be included in the analysis. The two methods gave very similar results.

\section{a. Wet periods}

The wet-period composite mean and anomaly patterns for daily precipitation, sea level pressure (SLP), and the vector wind at 850 and $200 \mathrm{hPa}$ are shown in Fig. 20. The composite mean patterns for wet periods (upper panels) feature daily rainfall values exceeding $20 \mathrm{~mm}$ in a large portion of the WCB region, with values less than $6 \mathrm{~mm}$ covering northern, northeastern, and southern Brazil. A region of low pressure (Chaco low) is evident over Paraguay, with a trough extending eastward to southeast Brazil. A low-level ( $850 \mathrm{hPa})$ cyclonic circulation is centered near the border of Paraguay and Brazil, with a strong fetch of west to northwest flow extending from the western Amazon to southeast Brazil. Anticyclonic circulation dominates the upper levels (200 hPa) over most of tropical and subtropical South America, with a center over Bolivia and strong subtropical westerly winds south of the center.

The composite anomaly patterns for wet periods (lower panels) feature positive rainfall anomalies over Brazil west of $45^{\circ} \mathrm{W}$ in the latitude band $5^{\circ}-25^{\circ} \mathrm{S}$, with values 

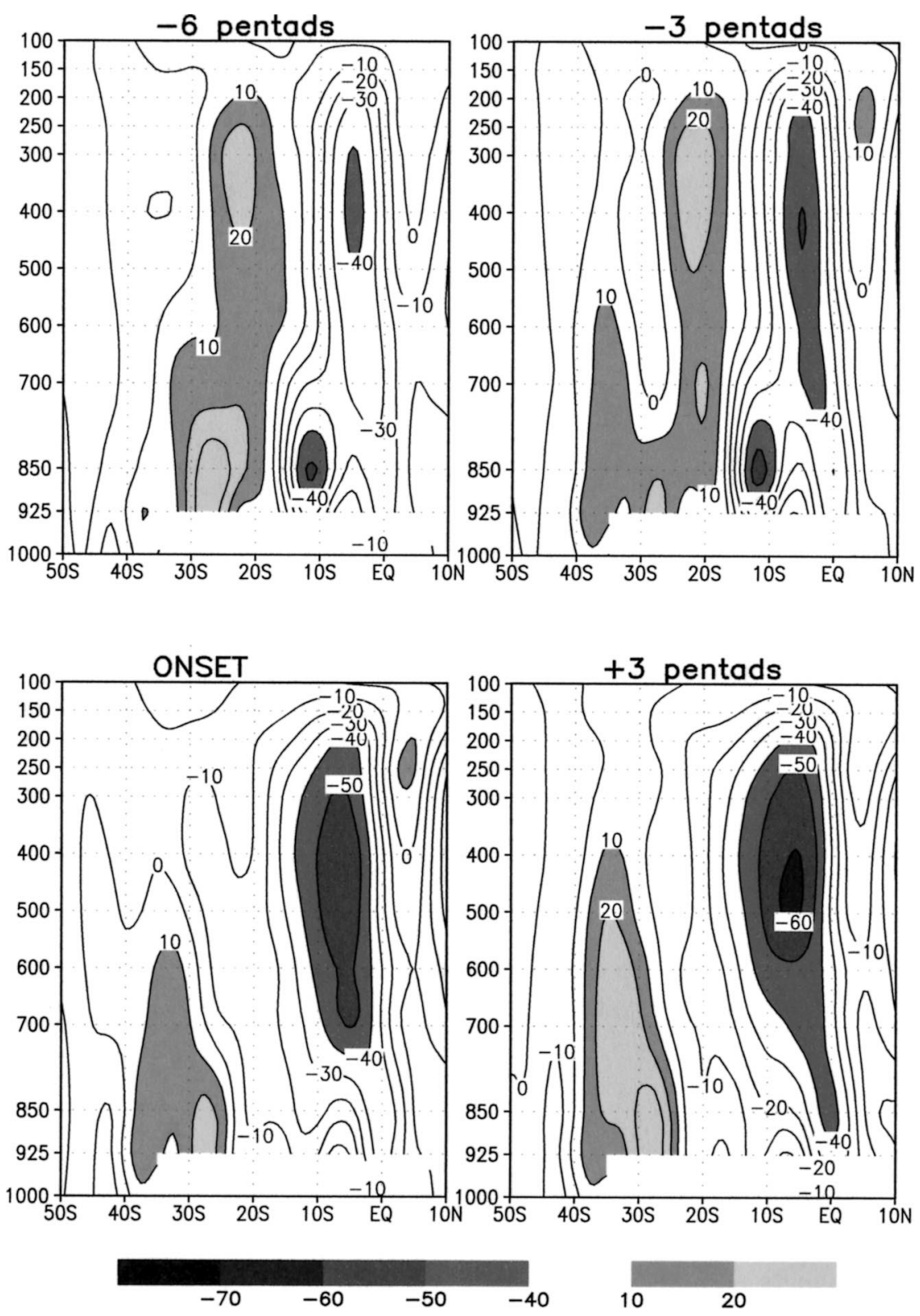

FIG. 15. Pressure vertical velocity $\left(\mathrm{hPa} \mathrm{day}^{-1}\right)$ composites, averaged over $50^{\circ}-60^{\circ} \mathrm{W}$, for the period prior to and immediately following the rainy season onset.

up to $12 \mathrm{~mm} \mathrm{day}^{-1}$ in the center of the region. Negative SLP anomalies and anomalous low-level cyclonic circulation are found over southern Brazil, while farther south positive SLP anomalies are found over Argentina. The anomalous pressure gradient between southern Brazil and Argentina gives rise to anomalous southeast winds at $850 \mathrm{hPa}$ over northeastern Argentina, Uruguay, extreme southern Brazil, and Paraguay. Anomalous lowlevel west to northwest winds are found over central Brazil, extending from the western Amazon east-southeastward to the southeast coast. At upper levels anomalous anticyclonic circulation dominates Brazil north of $22^{\circ} \mathrm{S}$, with anomalous westerlies over Brazil between $10^{\circ}$ and $25^{\circ} \mathrm{S}$. Farther south, anomalous cyclonic circulation is evident over extreme southern Brazil and northeastern Argentina.

\section{b. Dry periods}

The composite mean patterns for dry periods (upper panels in Fig. 21) feature daily rainfall values generally less than $4 \mathrm{~mm}$ in WCB, with values greater than 10 $\mathrm{mm}$ covering northwestern, northern, and portions of southern Brazil. The Chaco low is located over northern 

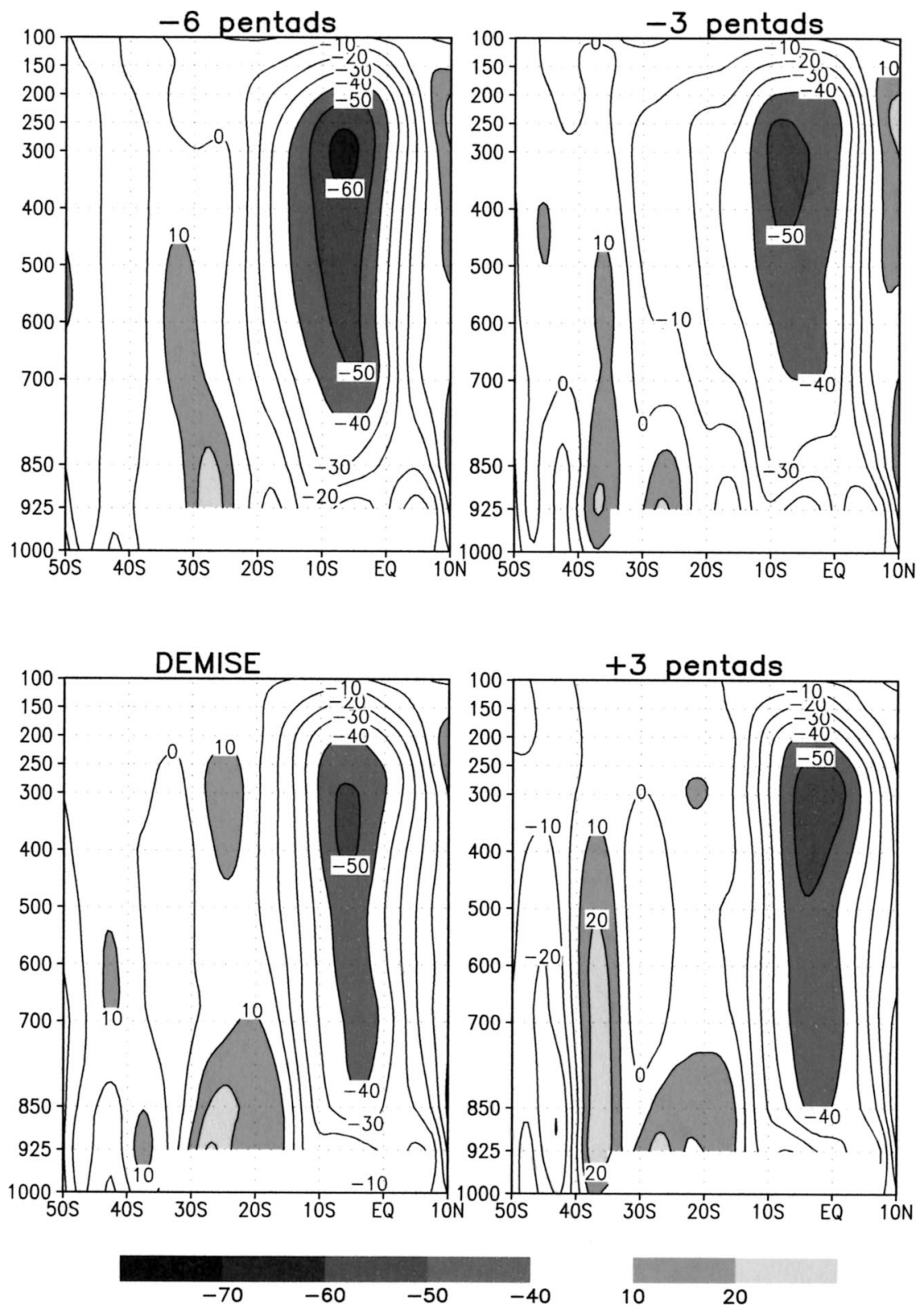

FIG. 16. As in Fig. 15 except for the rainy season demise.

Argentina, and a ridge of high pressure extends from the western Atlantic westward across Brazil near $20^{\circ} \mathrm{S}$. Low-level $(850 \mathrm{hPa})$ anticyclonic circulation covers south-central Brazil, with east to northeast flow extending from the Atlantic westward to the border of Brazil and Bolivia, and a strong northwesterly low-level jet from northern Bolivia southeastward to southern Brazil. Anticyclonic circulation dominates the upper levels $(200 \mathrm{hPa})$ over central South America, with a center over Paraguay. Upper-level cyclonic circulation extends from the central Amazon east-southeastward to the Brazil/Atlantic coast near $12^{\circ} \mathrm{S}$.

The composite anomaly patterns for dry periods (lower panels, Fig. 21) show nearly the opposite features to those described above for wet periods. Negative rainfall anomalies are found over central Brazil, with values as low as $-8 \mathrm{~mm} \mathrm{day}^{-1}$ in WCB. Positive SLP anomalies and anomalous low-level anticyclonic circulation are found over southern Brazil, while farther south negative SLP anomalies are found over Argentina. The anomalous pressure gradient between southern Brazil and Argentina gives rise to anomalous northwest and west winds (anomalously strong low-level jet) at $850 \mathrm{hPa}$ over northeastern Argentina, Paraguay, Uruguay, and southern Brazil. Anomalous low-level east winds are found over central Brazil to the west of $45^{\circ} \mathrm{W}$. At upper levels anomalous cyclonic circulation dominates tropical Brazil north of $15^{\circ} \mathrm{S}$, with anomalous easterlies over 

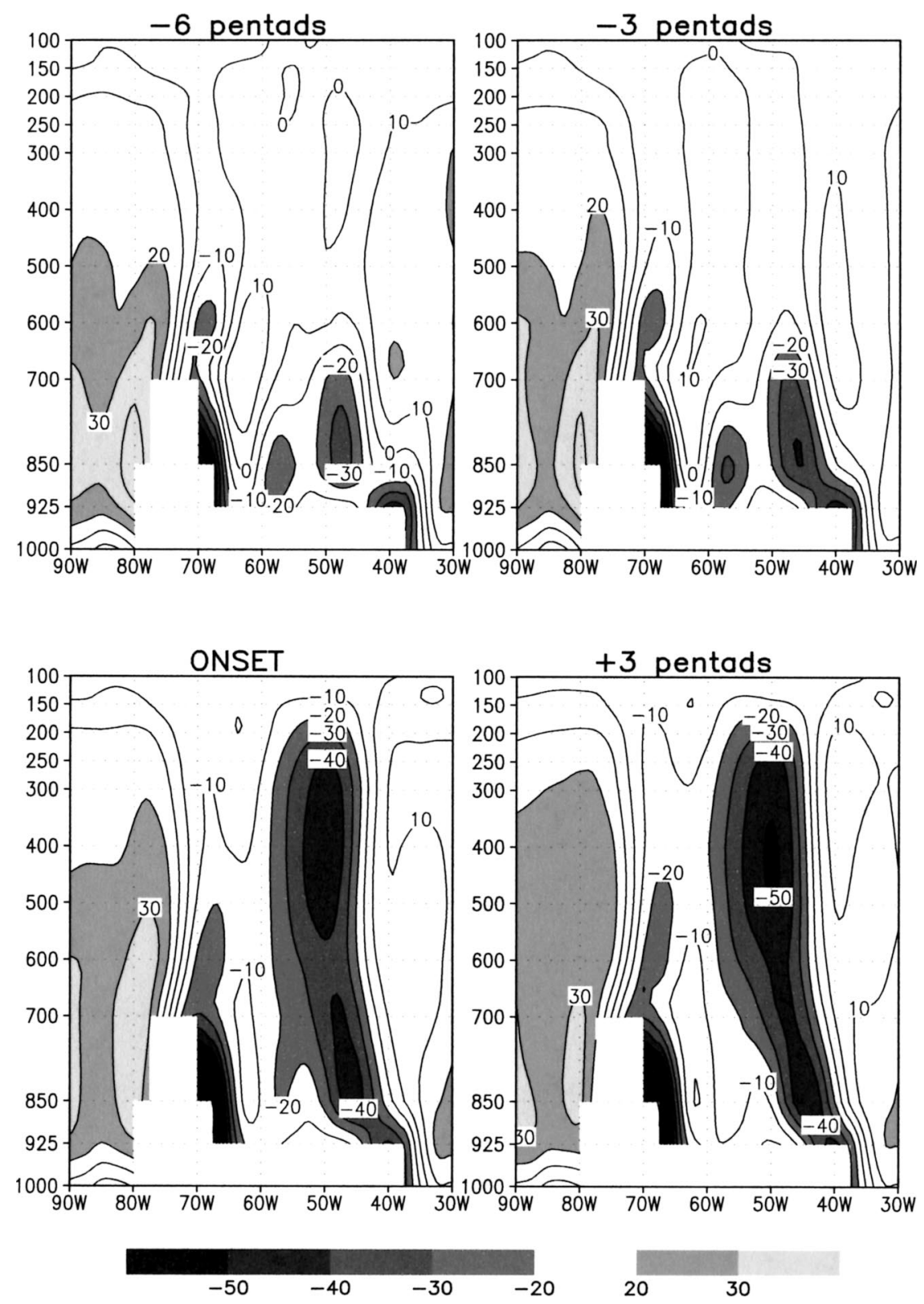

FIG. 17. Pressure-longitude composites for pressure vertical velocity $\left(\mathrm{hPa} \mathrm{day}^{-1}\right)$, averaged over $10^{\circ}-20^{\circ} \mathrm{S}$, for the period prior to and immediately following the rainy season onset.

Brazil between $12^{\circ}$ and $27^{\circ} \mathrm{S}$. Farther south, anomalous anticyclonic circulation is evident over extreme southern Brazil and northern Argentina.

\section{Discussion and conclusions}

The analysis presented in this paper provides an improved description of the mean annual cycle based on daily and pentad (5-day averaged) rainfall and atmospheric circulation data. Precipitation in the study region shows a rapid increase during the spring months (SON) and a rapid decrease in April. The rainiest period (more than $8 \mathrm{~mm} \mathrm{day}^{-1}$ ) is from December to February. There are distinct wet (7 months) and dry (5 months) seasons, with approximately $90 \%$ of the total annual rainfall occurring during October-April.

The mean atmospheric circulation was documented for the dry-to-wet (onset) and wet-to-dry (demise) transitions over west-central Brazil $\left(20^{\circ}-10^{\circ} \mathrm{S}, 60^{\circ}-50^{\circ} \mathrm{W}\right)$ for $21 \mathrm{yr}$ (1979-2000). This analysis shows that the region has several monsoon characteristics in addition to the distinct wet and dry seasons. Features of the 850and 200-hPa zonal wind fields over the study area show a reversal during the onset and demise transitions of the rainfall season. In early October, the lower- (upper-) level easterlies (westerlies) change to westerlies (east- 

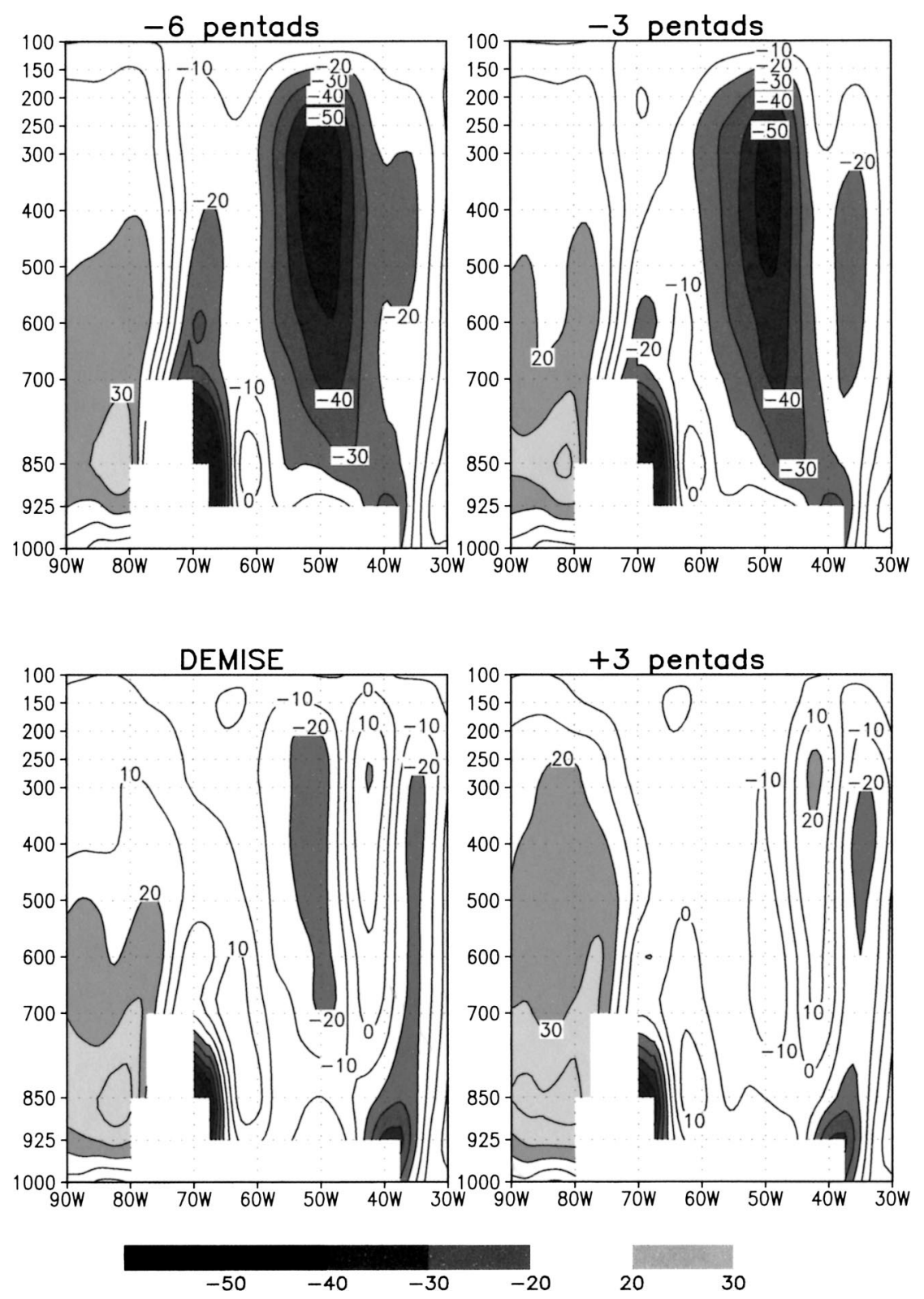

Fig. 18. As in Fig. 17 except for the rainy season demise.

erlies) to the east of the Andes returning to easterlies (westerlies) in mid-April. The lower-level westerlies extend east to $48^{\circ} \mathrm{W}$ during November through mid-January. Low-level (925-hPa) temperature is highest and specific humidity is lowest at the end of the dry season and beginning of the wet season (August-October). Specific humidity begins to increase just before the onset of the rainy season, while low-level temperatures are near their maximum. These features tend to destabilize the atmosphere just prior to the onset of the rainy season.

The identification of the onset and the demise dates for each rainy season over west-central Brazil during the period from July 1979 to June 1997 shows that the onset occurs between the pentads centered on $15 \mathrm{Sep}-$ tember and 14 November and the demise occurs between the pentads centered on 3 April and 3 May. There is considerably more variability in the onset dates than in the demise dates, which implies that the onset date may be somewhat dependent on transient systems to initiate and organize deep convection.

The deep convection starts over the northwest portion of the South America (e.g., Marengo et al. 2001; Kousky 1988), with a connection to the Pacific ITCZ. During the withdrawal phase, the deep convection overall is more active than during the onset phase, and it shows a connection to the Atlantic ITCZ.

Similar to the Asian monsoon, the South American monsoon features variability within the rainy season, 
1979

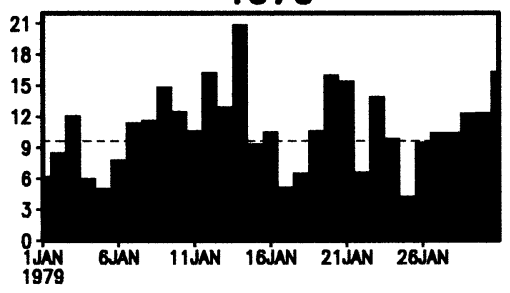

1982

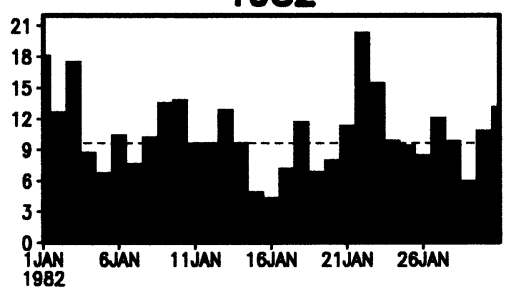

1985

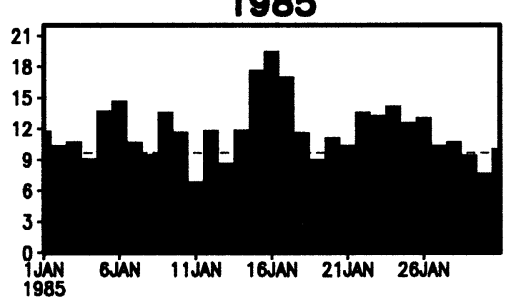

1988

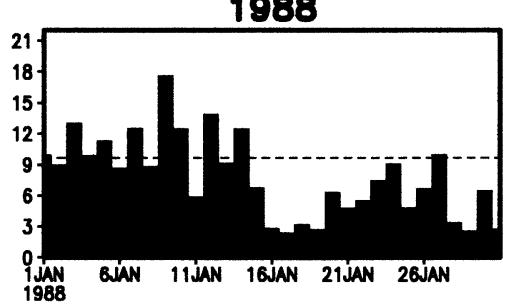

1991

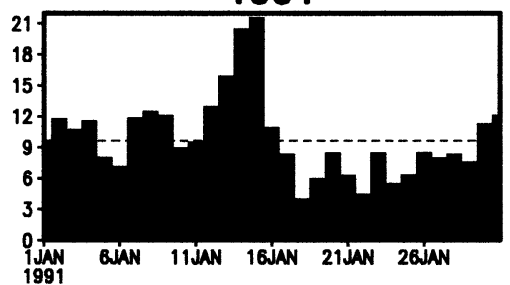

1994

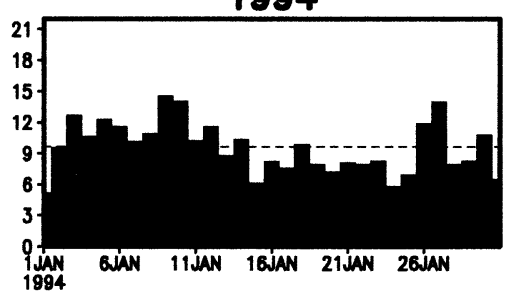

1980

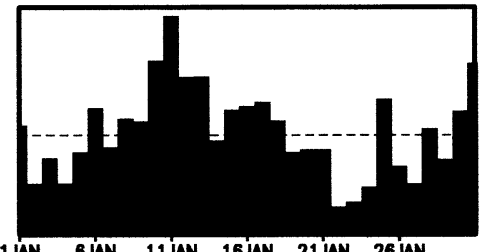

1JNN GJAN 11JAN 16JAN 21 LAN 26JAN

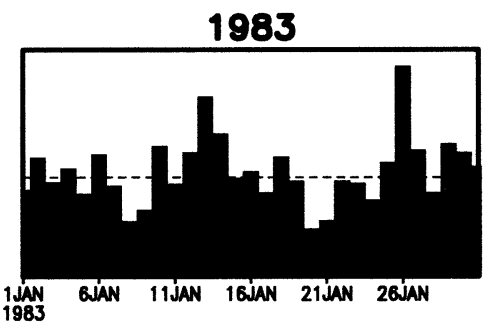

1986

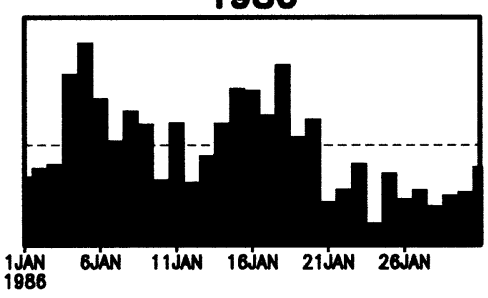

1989

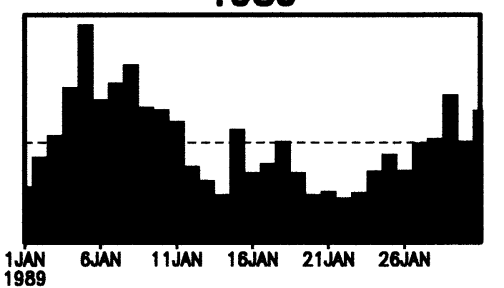

1992

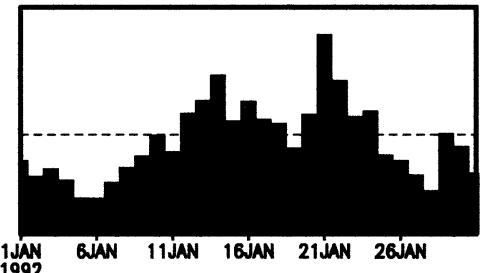

1995

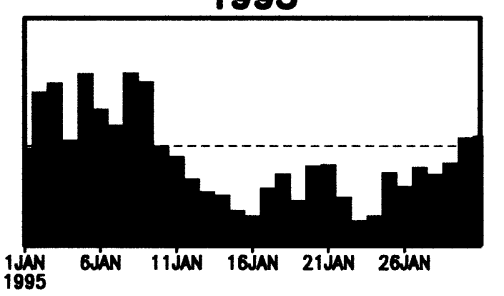

1981

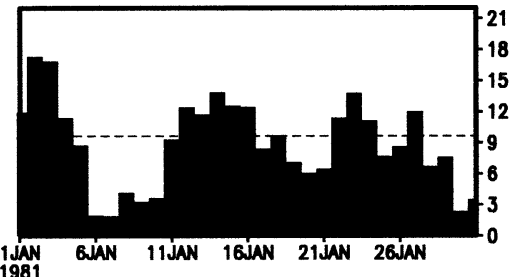

1984

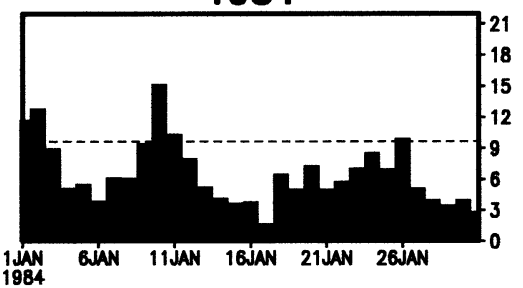

1987

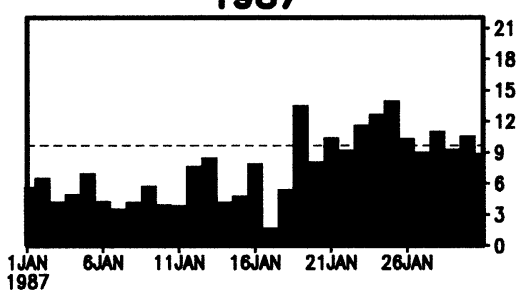

1990

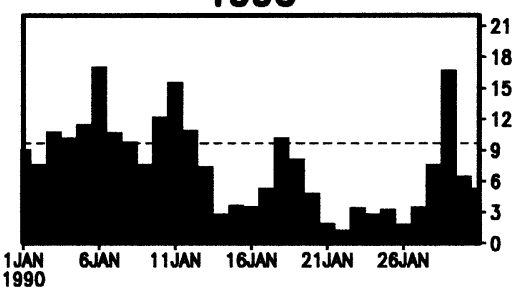

1993

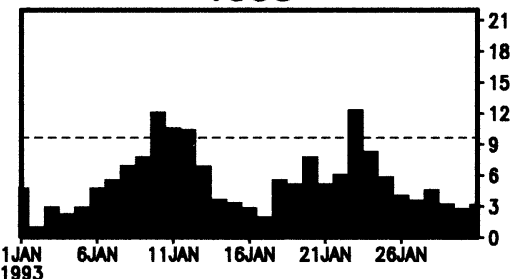

1996

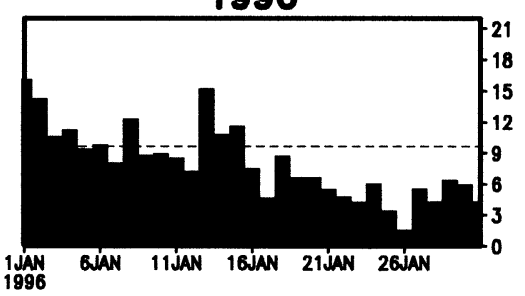

FIG. 19. Jan daily precipitation (mm) for WCB for each year from 1979 through 1996. The 1979-95 Jan mean daily precipitation is indicated by the horizontal dashed line in each panel. 

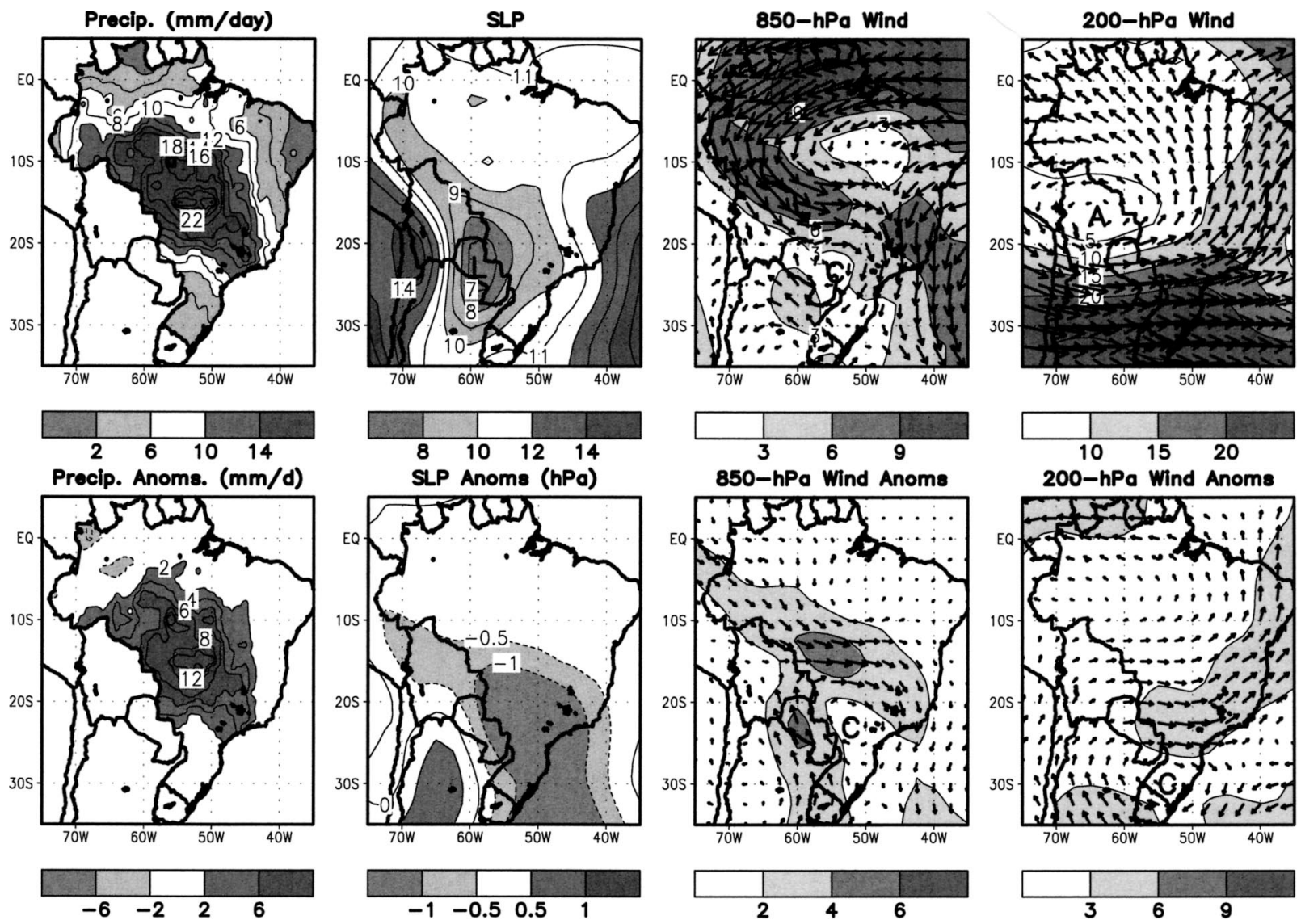

FIG. 20. (top) Composite mean and (bottom) anomalies of precipitation $\left(\mathrm{mm} \mathrm{day}^{-1}\right)$, sea level pressure (hPa, with $1000 \mathrm{hPa}$ subtracted from the mean), 850-hPa vector wind $\left(\mathrm{m} \mathrm{s}^{-1}\right)$, and 200-hPa vector wind $\left(\mathrm{m} \mathrm{s}^{-1}\right)$ for the largest 30 values of Jan daily precipitation in WCB during the period 1979-97. Contour intervals are $2 \mathrm{~mm} \mathrm{day}^{-1}$ for mean and anomalous precipitation, $1 \mathrm{hPa}(0.5 \mathrm{hPa})$ for mean (anomalous) sea level pressure, 3 (2) $\mathrm{m} \mathrm{s}^{-1}$ for 850-hPa mean (anomalous) wind speeds, and 5 (3) $\mathrm{m} \mathrm{s}^{-1}$ for 200-hPa mean (anomalous) wind speeds.

which occurs on a variety of time scales. A comparison of atmospheric circulation composites, for extreme wet and dry periods in west-central Brazil, shows that nearly opposite anomalous circulation features accompany the two extremes. Dry (wet) periods in WCB feature positive (negative) SLP and low-level anticyclonic (cyclonic) anomalies over southern Brazil. In addition, dry (wet) periods within the rainy season feature low-level easterly (westerly) winds over west-central Brazil, which is a prominent feature observed prior to (after) the onset of the rainy season. The relationship between low-level wind anomalies and precipitation, shown in this paper, is consistent with the results of Jones and Carvalho (2002). In their study, OLR, precipitation, and 850-hPa wind composites were constructed, based on the $850-\mathrm{hPa}$ wind anomalies in a smaller region just west of WCB, for active (westerly anomalies) and break (easterly anomalies) phases of the South American monsoon. Thus, composites based on either low-level winds or precipitation give similar results.

Previous studies have shown that mid- and low-latitude transient systems (e.g., midlatitude frontal systems and subtropical upper-level cyclonic vortices) have an important effect on the intensity and distribution of deep convection over tropical and subtropical South America (e.g., Kousky 1979; Kousky and Gan 1981; Liebmann et al. 1999). For example, upper-level cyclonic vortices, which develop at low latitudes over the Atlantic, frequently move westward and sometimes penetrate the continent. Due to the general downward vertical motion within these vortices, they tend to disrupt the pattern of deep convection as they move inland, resulting in a reduction in rainfall (Kousky and Gan 1981). The mean and anomalous dry-period composite upper-level circulation features (Fig. 21) are consistent with greaterthan-average cyclonic vortex activity over the continent.

On the other hand, strong summertime cold fronts, that occasionally reach low latitudes over South America and the western South Atlantic, may contribute to above-average rainfall over tropical South America (e.g., Kousky 1979) and may be important in modulating the intensity and position of the South Atlantic convergence zone (e.g., Liebmann et al. 1999; Silva and Kousky 2001). Features of the wet-period composites, such as negative SLP anomalies, mean and anomalous low-level cyclonic circulation over southern Brazil, and 

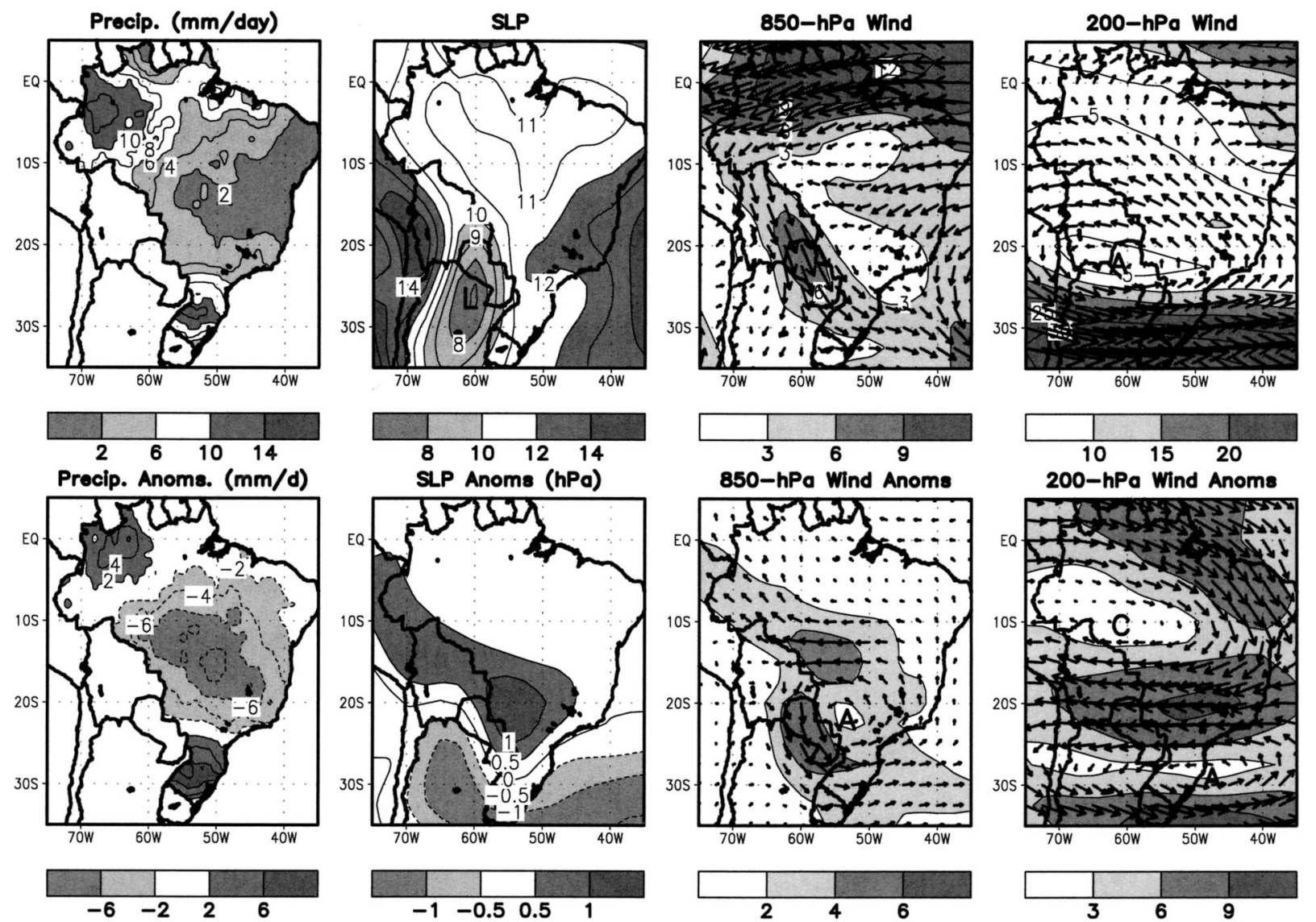

FIG. 21. As in Fig. 20 except for the smallest 30 values of Jan daily precipitation in WCB.

mean and anomalous southeasterly flow over northern Argentina, Paraguay, Uruguay, and southern Brazil (Fig. 20), are consistent with previous studies in indicating that frontal boundaries contribute to periods of aboveaverage rainfall over tropical South America.

Acknowledgments. The first author appreciates the hospitality of the International Research Institute for Climate Prediction during his visit to develop this study. The visit of the first author to IRI was supported by Fundacão de Amparo a Pesquisa do Estado de São Paulo (São Paulo State Foundation to Support Research) Project number FAPESP (2000/02420-7).

\section{REFERENCES}

Aceituno, P., 1988: On the functioning of the Southern Oscillation in the South American sector. Mon. Wea. Rev., 116, 505-525.

—, and A. Montecinos, 1993: Circulation anomalies associated with dry and wet periods in the South American Altiplano. Proc. Fourth Int. Conf. on Southern Hemisphere Meteorology, Hobart, Australia, Amer. Meteor. Soc., 330-331.

Berbery, E. H., and E. A. Collini, 2000: Springtime precipitation and water vapor flux over southeastern South America. Mon. Wea. Rev., 128, 1328-1346.

Casarin, D. P., and V. E. Kousky, 1986: Anomalias de precipitação no sul do Brasil e variações na circulação atmosférica (Precip- itation anomalies over Southern Brazil and variations in the atmospheric circulation). Rev. Bras. Meteor., 1, 217-231.

Davidson, N. E., J. L. McBride, and B. J. McAvaney, 1983: The onset of the Australian monsoon during winter MONEX: Synoptic aspects. Mon. Wea. Rev., 111, 496-516.

,$- \ldots$, and -1984 : Divergent circulations during the onset of the 1978-79 Australian monsoon. Mon. Wea. Rev., 112, 16841696.

De Maria, M., 1985: Linear response of a stratified tropical atmosphere to convective forcing. J. Atmos. Sci., 42, 1944-1969.

Figueroa, S. N., and C. A. Nobre, 1990: Precipitation distribution over central and western tropical South America. Climanálise, 5, 25-40.

_ P. Satyamurty, and P. L. Silva Dias, 1995: Simulations of the summer circulation over the South American region with an Eta coordinate model. J. Atmos. Sci., 52, 1573-1584.

Fu, R., B. Zhu, and R. Dickinson, 1999: How do atmosphere and land surface influence seasonal changes of convection in the tropical Amazon. J. Climate, 12, 1306-1321.

Gill, A. E., 1980: Some simple solutions for heat tropical circulation. Quart. J. Roy. Meteor. Soc., 106, 447-462.

Hendon, H. H., and B. Liebmann, 1990: A composite study of onset of the Australian summer monsoon. J. Atmos. Sci., 47, 22272240.

Holland, G. J., 1986: Interannual variability of the Australian monsoon at Darwin. Mon. Wea. Rev., 114, 594-604.

Horel, J. D., A. N. Hahmann, and J. E. Geisler, 1989: An investigation of the annual cycle of convective activity over the tropical Americas. J. Climate, 2, 1388-1403.

Jones, C., and L. M. V. Carvalho, 2002: Active and break phases in the South American monsoon system. J. Climate, 15, 905-914. 
Kalnay, E., and Coauthors, 1996: The NCEP/NCAR 40-Year Reanalysis Project. Bull. Amer. Meteor. Soc., 77, 437-471.

Kodama, Y.-M., 1992: Large-scale common features of subtropical precipitation zones (the Baiu frontal zone, the SPCZ, and the SACZ). Part I: Characteristics of subtropical frontal zones. J. Meteor. Soc. Japan, 70, 813-836.

Koteswaram, P., 1958: The easterly jet stream in the Tropics. Tellus, 10, 43-57.

Kousky, V. E., 1979: Frontal influences on northeast Brazil. Mon. Wea. Rev., 107, 1140-1153.

_- 1985: Atmospheric circulation changes associated with rainfall anomalies over tropical Brazil. Mon. Wea. Rev., 113, 1951-1957.

__ 1988: Pentad outgoing longwave radiation climatology for the South American sector. Rev. Bras. Meteor., 3, 217-231.

—_, and M. A. Gan, 1981: Upper tropospheric cyclonic vortices in the tropical South Atlantic. Tellus, 33, 538-551.

—_, and I. F. A. Cavalcanti, 1988: Precipitation and atmospheric circulation anomaly patterns in the South American sector. Rev. Bras. Meteor., 3, 199-206.

— lation and their relationship to precipitation anomalies with emphasis on the South American region. Rev. Bras. Meteor., 4, 351-363.

_ radiation and 250-mb circulation for the South American sector. J. Climate, 7, 1131-1143.

— ing Mean Climate over the Western Hemisphere (1979-1995). NCEP/Climate Prediction Center ATLAS, No. 3, 135 pp.

— - M. T. Kagano, and I. F. A. Cavalcanti, 1984: A review of the Southern Oscillation: Oceanic-atmospheric changes and related rainfall anomalies. Tellus, 36A, 490-504.

Krishnamurti, T. N., and H. N. Bhalme, 1976: Oscillations of a monsoon system. Part I: Observational aspects. J. Atmos. Sci., 33, 1937-1954.

Liebmann, B., G. N. Kiladis, J. A. Marengo, T. Ambrizzi, and J. D. Glick, 1999: Submonthly convective variability over South America and the South Atlantic convergence zone. J. Climate, 12, 1877-1891.

Madden, R. A., and P. R. Julian, 1972: Description of global-scale circulation cells in the Tropics with a 40-50 day period. J. Atmos. Sci., 29, 1109-1123.

Marengo, J. A., B. Liebmann, V. E. Kousky, N. P. Filizola, and I. C. Wainer, 2001: Onset and end of the rainy season in the Brazilian Amazon basin. J. Climate, 14, 833-852.

Matsuno, T., 1966: Quasi-geostrophic motions in the equatorial area. J. Meteor. Soc. Japan, 44, 25-42.

Murakami, T., and A. Sumi, 1982: Southern Hemisphere summer monsoon circulation during the 1978/79 WMONEX. Part II:
Onset, active and break monsoon. J. Meteor. Soc. Japan, 60, 649-671.

Nicholls, N., J. L. McBride, and R. J. Ormerod, 1982: On predicting the onset of the Australian wet season at Darwin. Mon. Wea. Rev., 110, 14-17.

Nogués-Paegle, J., and K. C. Mo, 1997: Alternating wet and dry conditions over South America during summer. Mon. Wea. Rev., 125, 279-291.

Ramage, C. S., 1971: Monsoon Meteorology. Academic Press, 296 pp.

Rao, G. V., and S. Erdogan, 1989: The atmospheric heat source over the Bolivian plateau for a mean January. Bound.-Layer Meteor., 46, 13-33.

Rao, V. B., and K. Hada, 1990: Characteristics of rainfall over Brazil: Annual variations and connections with the Southern Oscillation. Theor. Appl. Climatol., 42, 81-92.

_ I. F. A. Cavalcanti, and K. Hada, 1996: Annual variations of rainfall over Brazil and water vapor characteristics over South America. J. Geophys. Res., 101, 26 539-26 551.

Ropelewski, C. F., and M. S. Halpert, 1987: Global and regional scale precipitation patterns associated with the El Niño/Southern Oscillation. Mon. Wea. Rev., 115, 1606-1626.

Silva, V. B. S., and V. E. Kousky, 2001: Variabilidade intrasazonal de precipitação sobre o leste do Brasil durante o verão de 1999/ 2000. (Intraseasonal variability of precipitation over eastern Brazil during the summer of 1999/2000.) Rev. Bras. Meteor., 16, 187-199.

Silva Dias, P. L., W. Schubert, and M. De Maria, 1983: Large-scale response of the tropical atmosphere to transient convection. $J$. Atmos. Sci., 40, 2689-2707.

_ J. P. Bonatti, and V. E. Kousky, 1987: Diurnally forced tropical tropospheric circulation over South America. Mon. Wea. Rev. $115,1465-1478$

Troup, A. J., 1961: Variation in upper-tropospheric flow associated with the onset of the Australian summer monsoon. Indian J. Meteor. Geophys., 12, 217-230.

Virji, H., 1981: A preliminary study of summertime tropospheric circulation patterns over South America estimated from cloud winds. Mon. Wea. Rev., 109, 599-610.

Weickmann, K. M., 1983: Intraseasonal circulation and outgoing longwave radiation modes during Northern Hemisphere winter Mon. Wea. Rev., 111, 1838-1858.

_ , G. R. Lussky, and J. E. Kutzbach, 1985: Intraseasonal (30-60 day) fluctuations of outgoing longwave radiation and $250 \mathrm{mb}$ streamfunction during Northern Winter. Mon. Wea. Rev., 113, 941-961.

WMO, 1998: CLIVAR initial implementation plan. International CLIVAR Project Office, WCRP No. 103, WMO/TD No. 869, ICPO No. 14,356 pp.

Zhou, J., and K.-M. Lau, 1998: Does a monsoon climate exist over South America? J. Climate, 11, 1020-1040. 